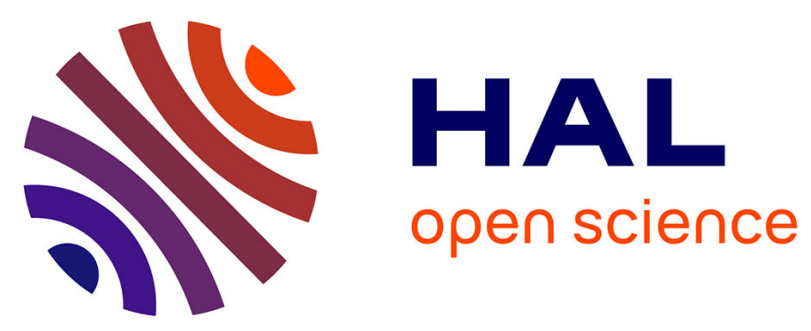

\title{
Badlands as a hot spot of petrogenic contribution to riverine particulate organic carbon to the Gulf of Lion (NW Mediterranean Sea)
}

Yoann Copard, Frédérique Eyrolle, Olivier Radakovitch, Alain Poirel, Patrick Raimbault, Stéphanie Gairoard, Christian Di-Giovanni

\section{To cite this version:}

Yoann Copard, Frédérique Eyrolle, Olivier Radakovitch, Alain Poirel, Patrick Raimbault, et al.. Badlands as a hot spot of petrogenic contribution to riverine particulate organic carbon to the Gulf of Lion (NW Mediterranean Sea). Earth Surface Processes and Landforms, 2018, 43 (12), pp.2495-2509. 10.1002/esp.4409 . insu-01953481

\section{HAL Id: insu-01953481 https://hal-insu.archives-ouvertes.fr/insu-01953481}

Submitted on 14 Dec 2019

HAL is a multi-disciplinary open access archive for the deposit and dissemination of scientific research documents, whether they are published or not. The documents may come from teaching and research institutions in France or abroad, or from public or private research centers.
L'archive ouverte pluridisciplinaire HAL, est destinée au dépôt et à la diffusion de documents scientifiques de niveau recherche, publiés ou non, émanant des établissements d'enseignement et de recherche français ou étrangers, des laboratoires publics ou privés. 


\section{Badlands as a hot spot of petrogenic contribution to riverine particulate Organic Carbon to the Gulf of Lion (NW Mediterranean Sea)}

Copard1 Yoann, Eyrolle ${ }^{2}$ Frédérique, Radakovitch ${ }^{2,3}$ Olivier, Poirel ${ }^{4}$ Alain, Raimbault ${ }^{5}$ Patrick, Gairoard ${ }^{3}$ Stéphanie, Di-Giovanni ${ }^{6}$ Christian

1- Normandie University, UNIROUEN, UNICAEN, CNRS, M2C, 76000 Rouen, France

2- Institut de Radioprotection et de Sûreté Nucléaire (IRSN), PRP - ENV, SRTE / LRTA, 13115 Saint-Paul-lès-Durance, France

3 - Aix Marseille Univ, CNRS, IRD, INRA, Coll France, CEREGE, Aix-en-Provence, France

4- Electricité de France (EdF) / DTG, 38040 Grenoble, France

5- Aix Marseille University, CNRS, IRD, Toulon University, Mediterranean Institute of Oceanography (MIO), UM 110, 13288, Marseille, France

6- Institut des Sciences de la Terre d'Orléans, UMR 7327, CNRS, Université d'Orléans, BRGM, 45071 Orléans, France

\section{Key points}

1-POC fluxes of the Rhône and Durance Rivers

2- petrogenic $P O C$ contribution to these POC fluxes

3- Badlands as a hot spot of pPOC delivery to the Gulf of Lion

This article has been accepted for publication and undergone full peer review but has not been through the copyediting, typesetting, pagination and proofreading process which may lead to differences between this version and the Version of Record. Please cite this article as doi: $10.1002 /$ esp.4409 


\section{Abstract}

Determining the riverine carbon fluxes to oceans is critical for an improved understanding of $\mathrm{C}$ budgets and biogeochemical cycles $(\mathrm{C}, \mathrm{O})$ over a broad range of spatial and time scales. Among the particulate organic carbon (POC) involved in these fluxes, those yielded by sedimentary rocks (petrogenic POC: pPOC) remain somewhat uncertain as to their source on continental surfaces. Based on time series from long-term observatories, we refine the POC and sediments flux of the Rhône River, one of the major tributaries to the Mediterranean Sea. Radiocarbon measurements on a set of riverine samples and - forward modelling were used to (i) determine a modelled pPOC content and pPOC / POC ratio for each sample set, (ii) assess a pPOC flux delivered to the NW Mediterranean Sea, and (iii) estimate the badlands contribution from the Durance catchment to both the pPOC and to sediment discharges. The weighted pPOC flux contributes up to $26 \%$ of the POC flux (145 Gg $\left.\mathrm{yr}^{-1}\right)$ discharged into the Mediterranean Sea, whereas the weighted pPOC content reaches 0.31 wt. \%. Despite their low contributive surface area $(0.2$ $\%$, badlands provide, respectively, $12,3.5$ and $14 \%$ of the pPOC, POC and sediment fluxes to the Rhône River. Consequently, such rocks can be considered as a major source of $\mathrm{pPOC}$ and sediments for the NW Mediterranean Sea and potentially for oceans. We suggest that river-dominated ocean margins, such as the Rhône River, with badlands in their catchment could export a significant amount of pPOC to the oceans.

\section{keywords:}

badlands, POC, suspended sediments, Rhône River, Gulf of Lion 


\section{Introduction}

Carbon exchange assessments between reservoirs in the critical zone, such as the atmosphere, water, soil and sediments, are important to understand the biogeochemical cycle (Petsch, 2014 and references therein). This is partially due to the variability of the particulate organic carbon (POC) fluxes from continents to oceans, which have a major role in the regulation of atmospheric $\mathrm{C}$ regardless of the timescale (Berner, 1982, Sarmiento and Gruber, 2006). Consequently, we need to discern the contribution of the different continental POC origins to these fluxes. POC origins can be classified into two main sources: (i) the recent POC (rPOC) produced by modern photosynthesis, primarily stored in soils and sediments and belonging to the short-term $\mathrm{C}$ cycle, and (ii) the petrogenic POC (pPOC) initially belonging to the long-term $\mathrm{C}$ cycle, but joining the short cycle when it is released within continental surfaces through erosion and weathering of sedimentary rocks (e.g., Copard et al., 2007). Early budgets of POC transfer by rivers did not thoroughly assess pPOC deliver to the oceans from continental surfaces (e.g., Berner, 1989, Ludwig et al., 1996), but there is now widespread evidences that pPOC contributes to many rivers (e.g., Kao and Liu, 1996, Hilton et al., 2011) and marine sediments (e.g., Sackett et al., 1974, Galy et al., 2008). At the global scale, $20-25 \%$ of the continental POC flux delivered to the world oceans, representing approximately $43 \mathrm{Tg} \mathrm{yr}^{-1}$, could have a petrogenic origin (Galy et al., 2015). However, some unknowns remain, in particular, the nature of the sedimentary rocks hosting this $\mathrm{pPOC}$, their organic carbon content (expressed in weight \%), and the identification of the major continental hot spots responsible for the export of pPOC to rivers. With an organic carbon concentrations frequently higher than the average content of most sedimentary rocks (Ronov and Yaroshevski, 1976), and a global stock of $1100 \mathrm{Pg}$ of 
C in the first metre of the (sub)-outcropping rocks (Copard et al., 2007), shales and clayey-carbonated rocks (e.g., marls) can be considered as relevant candidates to deliver pPOC to rivers due to surface processes. In addition, due to their mechanical properties (fine grain sizes, brittleness, and erodibility, e.g., Chorley et al., 1984), they can form badlands generally devoid of soils with a high gully density (Gallart et al., 2013). According to Nadal-Romero et al. (2011), these highly erodible surfaces enhance the sediment yield by a factor of 7 to 8 around the Mediterranean area, even though the badlands proportion in the catchments with an area over $10^{6}$ ha is rarely over $5 \%$. Therefore, badlands surfaces can be reasonably viewed as a major contributor to the $\mathrm{PPOC}$ input into rivers of this region.

With a suspended particulate matter (SPM) flux ranging from 1 to $11 \mathrm{Tg} \mathrm{yr}^{-1}$ over the last two decades (Ollivier et al., 2010, Eyrolle et al., 2012, Delmas et al., 2012) and due to the Nile River management (e.g., the Aswan dam), the Rhône River, despite being strongly anthropised (e.g. dams) is now one of the primary continental tributary of the Mediterranean Sea with the Po and Semani rivers (Milliman and Farnsworth, 2011) and supplies approximately one third of the fresh water brought to this sea (Ludwig et al., 2009). In the NW Mediterranean area, $95 \%$ of the sediments deposited in the Gulf of Lion are sourced from the Rhône River (Sadaoui et al., 2016). Accordingly, it is crucial to specify the primary sediment sources in the Rhône catchment and to discriminate the $\mathrm{rPOC}$ and $\mathrm{pPOC}$ fluxes to refine the lateral transfer of $\mathrm{C}$ from continental surfaces to the Mediterranean Sea and the $\mathrm{C}$ budget at this regional scale. Among the main tributaries of the Rhône River, the Durance River drains approximately $233 \mathrm{~km}^{2}$ of the bare Mesozoic badlands locally named Terres Noires (Rey et al., 2007). Even though there are no direct measurements of the contribution of SPM or pPOC fluxes from the badlands to the sedimentary and 
POC fluxes of the Durance and Rhône Rivers, we believe that these surfaces would significantly contribute to the SPM and PPOC of both rivers. The significant decrease in ${ }^{14} \mathrm{C}$ activity of SPM of the Rhône River, sampled downstream the confluence Rhône / Durance rivers, was previously attributed to the dilution of the SPM in the Durance River, which is depleted in ${ }^{14} \mathrm{C}$ (Eyrolle-Boyer et al., 2015). Badlands erosion could also contribute $27 \%$ of the pPOC discharged to the Mediterranean Sea (Graz et al., 2012). However, this first estimation based on the extrapolation of sediment yield from small instrumented catchments, and the previously acquired Rhône River POC flux of 44 to $200 \mathrm{Gg} \mathrm{yr}^{-1}$ (Ludwig et al., 1996, Sempéré et al., 2000) needs to be updated in order to refine the OC budget and the role of rivers in the lateral transfer of C. Three objectives motivated this study:

(i) Reassessing the POC fluxes exported by the Durance and Rhône Rivers using time series data of sediment discharges, SPM concentrations and POC concentrations,

(ii) Determining the SPM pPOC content of these two rivers and the petrogenic carbon concentrations in the POC fluxes, and

(iii) Estimating the Durance catchment badlands contribution to the organic carbon flux delivered to the Mediterranean Sea.

Methodologies used in this work consist of bulk organic (Rock-Eval 6 pyrolysis) and isotopic $\left({ }^{14} \mathrm{C}\right)$ geochemistry performed on SPM and flood sediment samples from these rivers. These results are discussed in the context of a regional $\mathrm{C}$ budget and in a global framework where we compare our results to the $\mathrm{pPOC/POC}$ ratio from other rivers. We concluded that badlands surfaces should be considered a major continental contributor of sediment and PPOC to rivers and, subsequently, to oceans. 


\section{Study area and badlands distribution}

Samples from badlands area were collected from two instrumented catchments of Draix (Laval and Brusquet), belonging to the French Network of Drainage Basins (RBV). This network is a part of the French System of long-term Observation and Experimentation for environmental REsearch (SOERE, fig. 1). These two drainage basins are representative of badlands surfaces located in the Durance catchment (Brochot, 1993) and are composed of Upper Toarcian to Oxfordian marls or marly limestones. Estimates of the surface area of the Badlands come from two sources. A bare badlands area of $119 \mathrm{~km}^{2}$ with active erosion processes was estimated by coupling the DEM (75 $\mathrm{m}$ resolution), the geological maps covering the Durance catchment (Rouire et al., 1979a, b, 1980, Kerchove et al., 1980), with the CLC2 2006 code from the CORINE Land Cover inventory (fig. 2). This spatial extension is approximately half of a previously mapped area of $233 \mathrm{~km}^{2}$ (Rey et al., 2007), a difference due to the input of Cretaceous rocks in the previous extension and the restricted use of the class "open space without or with little or no vegetation" labelled for bare badlands (CORINE Land Cover class number 33). In this work, we use a mean value of $176 \pm 57 \mathrm{~km} 2$ for these surface estimates. Such highly erodible surfaces, primarily distributed in the middle Durance, represent only $1.2 \%$ of the Durance catchment area and less than 0.2 \% of that of the Rhône.

The Durance River headwaters are in the Alpine mountains at the French-Italian border and join the Rhône River south of Avignon. The catchment covers 14,400 $\mathrm{km}^{2}$, and the river has a mean slope of $3 \%$ over $200 \mathrm{~km}^{2}$ primarily with a torrential regime. Approximately $30 \%$ of the water is diverted towards the Berre pond or is used for electricity supply. At Bonpas (fig. 1), the annual mean flow is $187 \mathrm{~m}^{3} \mathrm{~s}^{-1}$, and the annual and decennial flood discharges are 743 and $2,500 \mathrm{~m}^{3} \mathrm{~s}^{-1}$, respectively 
(www.eaufrance.fr). From 1860 to 2007, the mean annual SPM flux had a strong

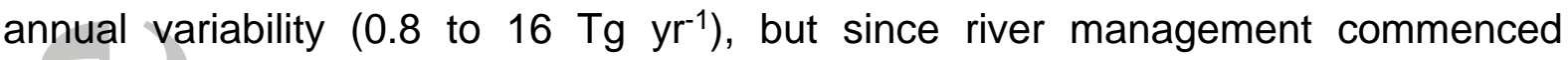
(1950s), it did not exceed 4.7 $\mathrm{Tg} \mathrm{yr}^{-1}$ (Poirel, 2009, Bertier and Bouchard, 2007).

The Rhône River originates in the Swiss Alps (Valais canton) and joins the Gulf of Lion (NW Mediterranean Sea) after flowing $800 \mathrm{~km}$ through France (catchment surface: $99800 \mathrm{~km}^{2}$ ). At Beaucaire, $50 \mathrm{~km}$ from the river mouth, the mean annual flow rate between 1920 and 2007 was $1700 \mathrm{~m}^{3} \mathrm{~s}^{-1}$. The average flow rates for the annual and decennial floods reach 4930 and $7570 \mathrm{~m}^{3} \mathrm{~s}^{-1}$, respectively (www.eaufrance.fr). In Arles, ten kilometres downstream from Beaucaire, the river is divided into two main drains branches: the Petit and Grand Rhône Rivers, with the latter representing approximately $90 \%$ of the water flow to the Mediterranean Sea. With a range between 2 and $26 \mathrm{Tg} \mathrm{yr}^{-1}$, a strong annual variability is observed for the sediment flux (e.g., Pont et al., 2002, Eyrolle et al. 2012, Sadaoui et al., 2016). The northwestern Mediterranean area is strongly influenced by the Rhône River, where $95 \%$ of the solid load inputs to the Gulf of Lion have a Rhodanian origin (Sadaoui et al., 2016).

\section{Materials}

3.1 Available data for the suspended sediment load, water discharge and POC flux Since 2001, the Durance River time series data of the annual SPM flux (tab. 1) were obtained via hourly measurements of turbidity and daily water flow $\left(\mathrm{m}^{3} \mathrm{~s}^{-1}\right)$ from the Bonpas Dam water budget (fig. 1) monitored by the national company Electricite de France (EdF) and more recently by the Rhône Sediment Observatory (OSR). From 1990 to 2001, SPM fluxes at Bonpas Dam were calculated following an unpublished 
hydro-sedimentary model developed by Electricité de France (Poirel, 1998, Bertier and Bouchard, 2007).

For the Rhône River, SPM samples and measurements (SPM and POC concentrations, water flow) were collected at the SORA monitoring station (Arles, fig.

1) by the French long-term observation program MOOSE (Mediterranean Ocean Observing System on Environment). Principles for SPM and POC fluxes calculation are described in section 5.1. From 2005 to 2014, annual SPM fluxes were determined from the daily SPM concentrations $\left(\mathrm{mg} \mathrm{L}^{-1}\right)$, and daily water discharge $\left(\mathrm{m}^{3} \mathrm{~s}^{-1}\right.$ ), while POC daily concentrations (in $\mu$ moles $\mathrm{C} \mathrm{L}^{-1}$ ) were used from 2007 to 2014 (tab. 1). However, when the flows were higher than $3000 \mathrm{~m}^{3} \mathrm{~s}^{-1}$ or when a flood was expected, samples were collected 2 to 6 times per day. From 1990 to 2004 (missing year: 1997 and 2000), SPM and flow time series data were derived from Pont et al. (2002). From 1990 to 1996, annual POC fluxes were obtained from Sempéré et al. (2000) and were modelled from 1997 - 2006 (cf. section 5.3).

\subsection{Sediment samples (SPM, FS and BS)}

The nature and origin of samples and analysis results are listed in table 2. SPM samples were collected from either water decantation or water centrifugation, while flood sediments (FS) were collected directly from the riverbanks and sieved at $2 \mathrm{~mm}$. Seven SPM and two river bed sediments (BS) sampled between 1999 and 2007 from instrumented badlands catchments were used in this study and were subjected to radiocarbon analyses. Their POC contents were determined using RE6 pyrolysis or were extracted from the literature (Graz et al., 2012). POC data previously published for more than 60 SPM samples were also used in this work (Copard et al., 2006, Graz, 2009; Graz et al., 2012). 
For the Durance River, 3 FS and 6 SPM samples collected between 2010 and 2015 during floods were used in this study (fig. 1). These SPM samples are representative of the river sediment load since approximately 77 to $85 \%$ of the sediment discharge occurred $2 \%$ of the time during the period $2001-2014$ (Electricite de France, pers. com.). All these samples were subjected to Rock-Eval 6 analyses for the quantification of their POC content. Radiocarbon measurements were performed on five samples (tab. 2). These samples were collected downstream of the diversion to the Berre pond. For the Rhône River, 17 SPM samples were collected between 2009 and 2014 at the SORA monitoring station (Arles, fig. 1) and were subjected to ${ }^{14} \mathrm{C}$ and bulk geochemical investigations to quantify their POC content (tab. 2).

\section{Methods}

\subsection{POC analyses}

In this study, POC content (in wt. \%) was obtained using either the POC and SPM concentrations from the SORA station for the Rhône River SPM or using a bulk organic geochemistry method (Rock-Eval 6 (RE6) pyrolysis). RE6 pyrolysis consists of pyrolysis and then combustion to perform a complete thermal degradation of OM. First, $50-80 \mathrm{mg}$ of previously crushed sample is pyrolyzed in an oven at a temperature range of $200-650{ }^{\circ} \mathrm{C}$ at $25{ }^{\circ} \mathrm{C} \mathrm{min}-1$, where pyrolysis effluents are transported via nitrogen. Hydrocarbons are quantified with a Flame Ionization Detector, while the yield of oxygenate compounds $\left(\mathrm{CO}_{2}\right.$ and $\left.\mathrm{CO}\right)$ are quantified via Infra-Red cells. This pyrolysis stage provides an organic $\mathrm{C}$ concentration (pyrolyzed carbon, expressed in wt. \%). The second stage consists of oxidation in an oven and of the pyrolyzed carbonaceous residue being subjected to a temperature between 
$400{ }^{\circ} \mathrm{C}$ and $750^{\circ} \mathrm{C}$. Oxidation effluents are transported via air, and only $\mathrm{CO}_{2}$ and $\mathrm{CO}$ are quantified with IR cells. A residual or remaining organic C concentration is determined during this last stage. The POC value is the sum of these two organic $C$ fractions. The primary advantage over other classical methods used for POC analyses is the absence of chemical pretreatments due to the thermal decomposition of the carbonates (Lafargue et al., 1998 for principles of the method).

\subsection{Radiocarbon analyses}

${ }^{14} \mathrm{C}$ contents were analysed using an accelerator mass spectrometer. Sample preparation consisted of washing the sample $(0.5 \mathrm{M} \mathrm{HCl}, 0.1 \mathrm{M} \mathrm{NaOH})$ and then drying it under a vacuum to eliminate the carbonates. Decarbonized samples were then sealed in quartz tubes under a vacuum with an excess of $\mathrm{CuO}$ and silver wire. Tubes were introduced into a furnace at $835^{\circ} \mathrm{C}$ for 5 hours to convert the organic carbon into $\mathrm{CO}_{2}$. The quartz tubes were then broken under a vacuum to release, dry, measure, and collect the $\mathrm{CO}_{2}$. The graphite target was obtained with a direct catalytic reduction of the $\mathrm{CO}_{2}$, using Fe powder as a catalyst. The reduction reaction occurs at $600^{\circ} \mathrm{C}$ with excess $\mathrm{H}_{2}\left(\mathrm{H}_{2} / \mathrm{CO}_{2}=2.5\right)$ and was complete after 4-5 hr. The iron-carbon powder was pressed into a flat pellet and stored under pure argon in a sealed tube. To reduce contamination from modern carbon or memory effects, all quartz and glass dishes were burned at $450^{\circ} \mathrm{C}$ for at least $5 \mathrm{hr}$. A turbo-molecular pump reaching $10^{-6}$ mbar was used to evacuate the vacuum lines. Measurements were performed using the Artemis facility: a 3 MV NEC Pelletron Accelerator coupled with a spectrometer dedicated to radiocarbon dating, measuring ${ }^{12} \mathrm{C},{ }^{13} \mathrm{C}$ and ${ }^{14} \mathrm{C}$ currents and counting the ${ }^{14} \mathrm{C}$ ions by isobaric discriminations. Analyses require 1 to $100 \mathrm{mg}$ of dry sample (to obtain $1 \mathrm{mg}$ of carbon). The resulting specific ${ }^{14} \mathrm{C}$ activity is 
expressed as Becquerel of ${ }^{14} \mathrm{C}$ per kilogram of total organic carbon (Bq kg-1 of $\mathrm{C}$ ) with a detection limit of $0.8 \mathrm{~Bq} \mathrm{~kg}^{-1}$ of $\mathrm{C}$, and an uncertainty of $0.1 \%$ for modern samples $(\mathrm{k}=2)$. In this work, Fraction Modern $(\mathrm{Fm})$ is derived from the normalized ${ }^{14} \mathrm{C}$ relative activity of the samples (pMC in \%, Mook and Van der Plitch, 1999) and the Modern C is given by the product POC (wt. \%). Fm (Galy et al., 2008).

\section{Results}

5.1 Calculation methods for SPM and POC fluxes of the Rhône River

Table 3 shows that the time series data (SPM concentration: [SPM] and water flow, Q) from the SORA monitoring station are not complete with up to one third of the data missing in some years (e.g., 2005). Therefore, we rebuilt the missing flow and SPM concentration values (fig. 3a). For [SPM], and contrary to a previous study (Eyrolle et al., 2012) that used a logarithm base 10-type equation to link these two variables, the best correlation is determined by using an exponential-type law (eq. 1): $[\mathrm{SPM}]=\mathrm{a} \mathrm{e}^{\mathrm{bQ}}(\mathrm{Eq} 1)$

units: ([SPM] in $\left.\mathrm{mg} \mathrm{L}^{-1}\right),\left(\mathrm{Q}\right.$ in $\left.\mathrm{m}^{3} \mathrm{~s}^{-1}\right)$

where $2.040<a<4.704$ and $1.210^{-3}<b<1.510^{-3}$

$0.386($ year 2010) $<r<0.756$ (year 2007), $p<0.001$.

Subsequently, for each day (or $n$ hours if a flood occurred) of each year, an SPM flux $\left(\mathrm{Tg}_{\mathrm{yr}}{ }^{-1}\right)$ was calculated based on the daily / multi-hour SPM concentrations and the water flow. These fluxes were then summed, and when daily measurements were missing, they were calculated as a proportion for the corresponding year. Missing data for the POC time series (2007-2014) increased some years up to $50 \%$ (2009, 
tab. 3) and were reconstructed using [SPM] and the following power-type law (fig. 3b, eq. 2):

$[P O C]=c[S P M]^{d}(E q 2)$

units: ([POC] in $\mu \mathrm{mol} \mathrm{L}-1),\left([S P M]\right.$ in $\left.\mathrm{mg} \mathrm{L}^{-1}\right)$

where $708.5<\mathrm{c}<1807.7$ and $6.4010^{-1}<\mathrm{d}<8.2710^{-1}$

$0.509($ year 2012) $<r<0.955$ (year 2011), $\mathrm{p}<0.001$.

To provide an annual POC flux ( $\mathrm{Tg} \mathrm{yr}^{-1}$ ), a POC value (in wt. \%) was first determined using the corresponding SPM and POC concentrations (eq. 3). Then, and classically, the daily POC flux was calculated using the POC content from equation 3 and the daily SPM flux (eq. 4). The annual POC flux calculation is similar to the annual SPM flux.

$P O C=([P O C] / 10[S P M]) . M c a r b o n(E q 3)$

units: POC: wt. $\%, M_{\text {Carbon }}=12 \mathrm{~g} \mathrm{~mol}^{-1}$

and

POC flux $=$ POC $.($ SPM flux $) / 10($ Eq 4)

units: (POC flux: Gg day-1), (SPM flux: $\mathrm{Tg}^{-1}$ day $\left.^{-1}\right)$.

\subsection{SPM and POC flux dynamics of the Rhône River}

Sediment transfer dynamics of the lower Rhône River can be illustrated with the daily SPM flux duration versus time graph (fig. 4a). During the 8 years of measurements, $50 \%$ of the SPM flux (Ts50) is delivered in 2 to $9 \%$ of the time, with an average of 4.3\% (tab. 4). This corresponds to 1 to 8 flood events per year, occurring primarily in late autumn or early winter. Such flood events account for $2 / 3$ of the total flood events during this long-term record. Similarly, POC transfer dynamics of the lower 
Rhône River can be described with the daily POC flux duration versus time graph (fig. 4b). Thus, during this 8 year record, $50 \%$ of the POC flux (TPOC50) is delivered in 2 to $8 \%$ of the time, with an average of $5.4 \%$ (tab. 4), a dynamic significantly similar to the SPM flux. This corresponds to 2 to 7 events, occurring primarily in late autumn and winter (months: 1, 2, 3, 11, and 12) and occasionally in early autumn (2013 and 2014) and spring $(2008,2010$ and 2013). There is no clear relationship between the spring and autumn occurrences with the annual POC fluxes.

\subsection{SPM and POC fluxes of the Durance and Rhône Rivers}

During the period 1990-2014, annual SPM fluxes exported by the Durance River range from 0.6 to $4.7 \mathrm{Tg} \mathrm{yr}^{-1}$ (tab. 1) with an inter-annual average of $2.1 \pm 0.9 \mathrm{Tg} \mathrm{yr}^{-1}$; indicating a large variability of sediment export. POC contents of the sediments transported by the Durance River were not previously documented and were calculated using the mean POC $(0.58 \pm 0.09$ wt. \%) determined by RE6 pyrolysis of the SPM and FS samples (tab. 2). Using this value and the SPM fluxes, the average POC flux from the Durance River was estimated at $12.4 \pm 5.3 \mathrm{Gg} \mathrm{yr}^{-1}$ from 1990 to 2014.

For the same study period, annual SPM fluxes from the Rhône River range between 0.98 and $19.69 \mathrm{Tg} \mathrm{yr}^{-1}$ with an inter-annual average SPM flux of $6.4 \pm 4.3 \mathrm{Tg} \mathrm{yr}^{-1}$ (tab. 2), a value fairly similar to previous estimates (e.g., Pont et al., 2002, Delmas et al., 2012). However, if the SPM fluxes are well documented, the POC fluxes are far less so. POC fluxes calculated in this work for the period 2007-2014 and those published in Sempéré et al. (2000) provide a linear relationship for the corresponding annual SPM flux (eq. 5): 
$y=20.4 x+15.36, R^{2}=0.96,($ Eq. 5$)$

This robust correlation finds its roots in the interdependence between these two parameters (eqs. 3 and 4). Nevertheless, equation 5 can be used to rebuild and estimate the missing inter-annual POC fluxes for the study period (tab. 1). Consequently, we estimate an inter-annual mean POC flux from the Rhône River to the Gulf of Lion of approximately $145 \pm 89 \mathrm{Gg} \mathrm{yr}^{-1}$, which is in the same order of magnitude as the most recently published value of $200 \mathrm{Gg} \mathrm{yr}^{-1}$ (Sempéré et al., 2000).

5.4 Petrogenic POC (pPOC) content and its contribution to the POC.

5.4.1 pPOC (wt. \%) assessment: a linear model approach

It is possible to assess a mean pPOC value (wt. \%) of SPM from rivers by plotting the POC content and the product of this value with the corresponding modern fraction (fig. 5, Galy et al., 2008, Blair et al., 2010). Classically, the pPOC is given when the line defined by equation 6 (see below) crosses the x-axis. However, in order to use this equation and to provide a PPOC content, three criteria must be met (Galy et al., 2008, Galy and Eglinton, 2011, Hilton 2017): (i) POC in SPM samples should be seen as a binary mixture of petrogenic and recent POC, (ii) the pPOC content should be relatively constant and homogenised whatever the studied sample and (iii) radiocarbon activity of $\mathrm{rPOC}$ (i.e. $\mathrm{rFm}$ ) is also relatively constant and homogenised. When these three conditions are met, the data plotted in the figure 5 must produce a perfect linear trend to predict the PPOC.

POC . Fm $=$ POC . rFm - pPOC . rFm (Eq. 6, with POC expressed in wt. \%)

If $\mathrm{POC} F \mathrm{~m}=0$, then $\mathrm{POC}=\mathrm{pPOC}$ 
Fm is the measured radiocarbon composition of the sample (modern fraction), and rFm corresponds to the radiocarbon composition of the rPOC (i.e., non-petrogenic POC) in the sample.

In the figure 5, correlation coefficients of the sample sets (tab. 2) vary from 0.58 (Rhône) to 0.85 (Durance). Samples from small-instrumented badlands catchment have a low correlation coefficient ranging from 0.01 (Brusquet) to 0.61 (Laval). In addition,, the distribution of the data is not well defined to validate this linear model well. The poor linear correlations seen in figure 5 raise doubt on the pPOC values obtained using Equation 6. If we consider that POC in SPM samples is a mixture of pPOC and $\mathrm{rPOC}$, the second and third conditions previously described are not fulfilled. The possible explanations are that: (i) the contribution of at least two sources of sedimentary rocks having their own pPOC value (for Durance and Rhône samples set), (ii) the contribution of various sources of recent material show variable rFM values, and (iii) the streams draining catchments only capture the variability at the small scale. The explanatory reasons also originate from the nature of the samples and in the size of the Rhône and the Durance catchments. Indeed, a high variability in $\mathrm{pPOC}$ content and in ${ }^{14} \mathrm{C}$ activity of $\mathrm{rPOC}$ might be expected since these are all SPM or flood samples collected at different times. These variabilities become even larger when the catchment size increases.

\subsection{2 pPOC (wt. \%) assessment: a forward model approach}

In order to assess a mean pPOC value and to calculate a pPOC flux for the different catchments, and because the linear modelling did not work, here we test a forward modelling technique by defining a rFm value and then estimate the pPOC content for 
each samples set. First, and since pFm is supposed to be equal at 0 , we rearrange equation 6 as:

$\mathrm{rPOC}=(\mathrm{Fm} . \mathrm{POC}) / \mathrm{rFm}($ Eq. 7$)$

where all terms of this equation are known with the exception of rFm. For the rPOC from the Durance and Rhône rivers, we then hypothesize two ages for rPOC: 100 and 1000 years BP. For the small badlands' catchments, only the age of 100 years is selected because these terrains are considered to be very erodible surfaces. Consequently, the rFm can be calculated given the age of OM as per Mook and Van der Plitch (1999), where, $r F m=E X P(-$ age / 8033) (Eq. 8)

Applied to an age of 100 and 1000 years BP for recent OM exported in rivers, rFm values are set to 0.99 or 0.88 . Accordingly, rPOC value can be estimated by using equation 7 (tab. 2), and the difference between POC and rPOC provides an estimate for the PPOC value for each sample (tab. 2). For the Laval and Brusquet catchments, pPOC contents are close to those of marls (e.g. Graz et al., 2012): 0.53 \pm 0.05 wt. $\%$ and $0.50 \square 0.18$ wt.\% respectively. For the Durance samples, and considering the two rFm values, pPOC reaches either $0.26 \square 0.12$ wt. $\%$ or 0.30

0.11 wt. $\%$ if the recent $\mathrm{OM}$ is 1000 or 100 years, respectively; for the Durance sample set, a pPOC value of $0.28 \square 0.11$ wt.\%, representing the mean of the two estimates, is considered. Following these two ages for recent $\mathrm{OM}$, the petrogenic organic fraction in the Rhône SPM samples exhibit a large variability (0.46 $\square 0.49$ wt.\% and $0.60 \square 0.55$ wt.\%) with an average close to $0.53 \square 0.52$ wt.\%.

However, for two of these samples set (the badlands' streams and the Rhône River), we can refine these data by introducing for the badlands, the importance of sediments exported by the Laval compared to that of the Brusquet; and for the 
Rhône River, the ratio between the daily POC flux of the sampling date (tab. 2) vs. the annual POC flux (tab. 1).

Based on data from this French Critical Zone Observatory, Laval stream exports 30 times more of sediments than the Brusquet stream, so a coefficient of $30: 1$ was applied to data from the Laval catchment. The average of $\mathrm{pPOC}$ from these badlands reaches $0.53 \square 0.05$ wt.\% (tab. 2).

For the Rhône river, as seen in the cumulative percentage of the POC flux versus the cumulative percentage of time (fig. 4b), the contribution of daily POC flux to the yearly POC flux is not homogeneously distributed. Using daily data collected at the gauging station at Arles (SORA), we have calculated a coefficient for each SPM sample corresponding to the ratio between the daily POC flux compared to the annual POC flux (tab. 1); to facilitate the reading and to produce a weighted average this coefficient was then multiplied by 1000 . These coefficients (tab. 2) are then applied to the pPOC value of each sample to estimate a weighted pPOC. Thus with rFm values of 0.88 and 0.99 , two new weighted average pPOC values of $0.27 \square 0.26$ wt.\% and $0.35 \square 0.32$ wt.\%, respectively were calculated. Accordingly, the mean pPOC content in samples of the Rhône River were estimated to be $0.31 \pm 0.29$ wt.\%.

\subsection{3 pPOC / POC ratio assessment with a forward model}

The pPOC / POC ratios, given for stream samples from badlands' catchments, range from 0.37 to 0.97 with a weighted (coefficient $30: 1$ ) average of $0.93 \square 0.01$ (tab. 2, fig. 6). This implies that most of the POC released by badlands' surfaces to streams has a petrogenic origin. For each sample from Durance, there are two ratios according to the two rFm value (section 5.4.2); when recent $\mathrm{OM}$ is aged (1000 years), the ratio ranges from 0.31 to 0.79 (average $0.46 \pm 0.19$ ), while for fresh and 
recent $\mathrm{OM}$ (100 years), the range is 0.38 to 0.82 (average $0.52 \pm 0.17$ ). The selected value of this ratio for the Durance samples set corresponds to the average between these two values: $0.49 \pm 0.18$, which means that approximately half of the POC carried by the Durance River has a petrogenic origin.

For the Rhône samples set, using the two rFm values the pPOC / POC ratio ranges from 0.00 to 0.44 (average $0.19 \pm 0.15$ ) when recent $O M$ is aged (1000 years), while for fresh and recent OM (100 years), the range is 0.00 to 0.49 (average $0.26 \pm 0.17$ ). When weighted by the coefficients, these ratio raise to $0.22 \pm 0.16$ and $0.30 \pm 0.17$ with mean ratio of $0.26 \pm 0.17$ for the Rhône samples set. Thus, approximately one quarter of POC delivered to the Mediterranean could be of petrogenic origin.

\section{5 pPOC fluxes}

Based on the POC flux $\left(12.4 \pm 5.3 \mathrm{Gg} . \mathrm{yr}^{-1}\right)$ and the pPOC / POC ratio $(0.49 \pm 0.18)$, the petrogenic POC flux delivered by the Durance to the Rhône River reaches $6.1 \pm$ 2.6 Gg $\mathrm{yr}^{-1}$. However, this petrogenic fraction includes badlands and other sedimentary rocks outcropping in the catchment. Among the main other sources of material in Durance River, the molasse formation (composed of coarse detritic materials more and less consolidated) is considered as strongly erodible (e.g. Chorley et al., 1984) and could significantly contribute to the sediment load as already seen for the Bléone River one of Durance's tributaries (Navratil et al., 2012); in addition, molasse outcrops are widespread in other areas of the Durance catchment (Rouire et al, 1979a, b, Kerchove et al., 1980). According to the mean total organic carbon (TOC) content of the sedimentary rocks (Ronov and Yaroshevski, 1980), it is reasonable to consider that molasses may hold a TOC content of 0.10 wt. \%. Hence, the badlands contribution is calculated using the 
following equations (eq. 9) accounting for a binary mixture between badlands (pPOCb) and molasse (pPOCm):

$a p P O C b+b p P O C m=0.28$, with $a+b=1$ (Eq. 9),

with $\mathrm{pPOCb}=0.53$ wt.\% (section 5.4.2).

The resolution of this equation shows that the badlands contribute to $42 \%$ of the petrogenic OC origin in riverine material from the Durance River. At the outlet of the Durance River, this implies that the badlands produce a pPOCb flux of $2.5 \pm 1.1 \mathrm{Gg}$ $\mathrm{yr}^{-1}$ and would contribute $\sim 20 \%$ of the POC flux.

pPOC flux from badlands outcropping in the Durance catchment can also be calculated following an another approach derived from the literature and considered here as an upstream approach. Indeed, with a pPOC yield of $52 \mathrm{Mg} \mathrm{km}^{-2} \mathrm{yr}^{-1}$ from $233 \mathrm{~km}^{2}$ of bare badlands erosion within the Durance catchment, it was previously assumed that the pPOCb flux (petrogenic POC flux delivered by the badlands) to the Gulf of Lion could reach $12 \mathrm{Gg} \mathrm{yr}^{-1}$ (Graz et al., 2012). This organic flux was refined in this study by considering a lower extent of the badlands surfaces $\left(119 \mathrm{~km}^{2}\right)$ and the amount of water and sediments diverted towards the Berre pond and other minor reservoirs (29\% in Bertier and Bouchard, 2007). Based on these considerations, the pPOCb flux would reach $4.4 \mathrm{Gg} \mathrm{yr}^{-1}$ and $8.6 \mathrm{Gg} \mathrm{yr}^{-1}$ if we consider the badlands cover $233 \mathrm{~km}^{2}$ (Rey et al., 2007). Using the average of the two surface estimates, the mean pPOCb flux delivered by the Durance River to the Rhône River would be $6.5 \pm 2 \mathrm{Gg} \mathrm{yr}^{-1}$. Using the average between these two approaches, the pPOC flux from the badlands reaches $4.5 \pm 1.5 \mathrm{Gg} \mathrm{yr}^{-1}$. Considering the ratio $\mathrm{pPOC} / \mathrm{POC}$ of 
0.93, the POC flux originate from badlands would be on the average of $4.9 \pm 1.5 \mathrm{Gg}$ $\mathrm{yr}^{-1}$

Based on the POC flux $\left(145 \pm 89 \mathrm{Gg} \mathrm{yr}^{-1}\right)$ and the weighted ratio pPOC / POC $(0.26$ 0.17 ) previously given in section 5.4 , the petrogenic POC flux delivered by the Rhône River to the NW Mediterranean Sea would be approximately $37.7 \pm 15.1 \mathrm{Gg}$

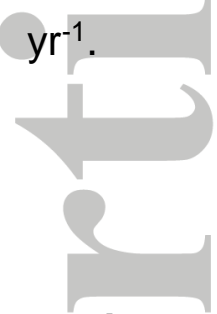

\section{Discussion}

6.1 SPM fluxes delivered by the Rhône River: contribution of the Durance River and the badlands hot spot

The Durance River significantly contributes to the SPM fluxes delivered to the Gulf of Lion (Sadaoui et al., 2016). These last authors report the major role of sedimentary rocks outcropping in the mountains (e.g., the Alps and Pyrénées) as a source of the solid fluxes delivered by coastal rivers to the Mediterranean Sea (Sadaoui et al., 2016). By using a model based on sedimentary mass balance, these authors estimated that the Durance River contributes $23 \%$ of the SPM flux transported by the Rhône River. Furthermore, Zebracki et al. (2015) used geogenic radionuclides as fingerprints of sedimentary masses transported during flood events to estimate that the Pre-Alpine tributaries (Durance, Ouvèze, Aigues, fig. 1) would account for 38 to $53 \%$ of the SPM flux delivered by the Rhône River. In our study, the Durance River contribution to the SPM load of the Rhône River is estimated at 32\% (fig. 7B), which agrees well with these previous estimates.

Based on the mean pPOC content of SPM (0.53 wt. \%), the ratio pPOC / POC of 0.93, and on the badlands contribution to the POC fluxes of the Durance River (4.9 
Gg $\mathrm{yr}^{-1}$, see section 5.5), SPM fluxes from badlands erosion can be determined and would reach $0.9 \square 0.4 \mathrm{Tg} \mathrm{yr}^{-1}$ (Fig 7B), which is approximately $40 \%$ of the sediment mass transported by this river, even though those sedimentary formations cover less than $1.5 \%$ of the total Durance catchment area. This high SPM flux contribution is twice lower than the calculation of Fournier (2004). Using the mean badlands surface, we estimate that the sediment yield could reach $5.10 \pm 3 \mathrm{Gg} \mathrm{km}^{-2} \mathrm{yr}^{-1}$, which is also similar to previous reports (e.g., Mathys et al., 2003).

At the Rhône catchment scale, the badlands contribution from the Durance catchment to the SPM fluxes transported in the lower Rhône River would reach approximately $14 \%$ (fig. 7B) with a surface area of approximately $0.2 \%$ (fig. $7 \mathrm{~A}$ ). This large SPM contribution associated with a very small erosive surface area was also reported for the Red Deer River in Alberta, where badlands contribute to $80 \%$ of the SPM fluxes transported by the river, while these rocks cover less than $2 \%$ of the total watershed surface area (Bryan and Campbell, 1986). For the NW Mediterranean Sea, the badlands can be considered as a major contributor of sediments transported to the marine environments.

The required time percentage (fig. $4 a$, tab. 4) to transport $50 \%$ of the SPM flux (mean $\mathrm{Ts}_{50}=4.3$ \%) approximates that published for the alpine Rhône River (i.e., $5.7 \%$ in Switzerland, Meybeck et al., 2003). For half of the studied period with Ts50 values lower than $3 \%$, the Rhône River, despite its catchment size $\left(10^{5} \mathrm{~km}^{2}\right)$, could be considered a mountainous catchment (Meybeck et al., 2003). The Rhône River transports most of its sediment load during flood events over a short time period (Sempéré et al., 2000, Pont et al., 2002, Rolland 2006). The significant flood event in November 2011 delivered $1.64 \mathrm{Tg}$ of SPM in five days, representing $66 \%$ of the annual SPM flux in that year. Additionally, the flood event of December 2003 
accounted for $83 \%$ of the annual SPM flux over several days (Ollivier et al., 2010). These two examples emphasize that such "extreme" events occur frequently in this area and should become more frequent in the context of climate change (Scoccimarro et al., 2016).

\subsection{POC flux of the Durance and Rhône Rivers}

These fluxes from the Rhône River tributaries are poorly documented. To our knowledge, only the Isère River, the other major tributary of the Rhône River, has had organic carbon (including the dissolved form) transports estimated at being approximately $37 \mathrm{Gg} \mathrm{yr}^{-1}$ (Nemery et al., 2012). Badlands contribute to $40 \%$ of the POC flux of the Durance River which, in turn, accounts for a minor contribution (8-9 \%) of the POC discharged by the Rhône River (fig. 7C vs 7B). At the Rhône scale, POC flux from badlands only contributes for approximately $3.5 \%$ (fig. 7C). This clearly signifies the dilution of the riverine sediment POC contents transported by the Durance River by the marly rocks from badlands sediments depleted in POC (the OC contents of marls range from 0.47 to 0.70 wt. \%; Copard et al., 2006, Graz et al., 2011). Hence, with values ranging from 0.55 to 0.74 wt.\%, SPM POC contents from the Durance River are among the lowest recorded in drainage basins worldwide (Roose et al., 2006). The Rhône River yields $1.45 \mathrm{Mg} \mathrm{km}^{-2} \mathrm{yr}^{-1}$ of POC, a yield higher than those published for other Mediterranean rivers, such as the Po and Tiber Rivers (Ludwig et al., 1996). However, this yield remains on the same order of magnitude as those calculated for southern Europe (1.242 $\mathrm{Mg} \mathrm{km}^{-2} \mathrm{yr}^{-1}$ ), and at this regional scale, the Rhône River provides approximately 12 \% of the POC transported to the continental shelf (Ciais et al., 2006). 
POC contents transported by the Rhône River are relatively low compared to those from other rivers. For example, SPM concentrations of approximately $10 \mathrm{mg} \mathrm{L}^{-1}$ have a mean POC content in the downstream Rhône River of $3.8 \pm 2.2$ wt. \%, whereas they are significantly higher in other hydrosystems $(6.5 \pm 3.2$ wt. \%; Roose et al., 2006). For SPM concentrations higher than $50 \mathrm{mg} \mathrm{L}^{-1}$, the mean POC contents (1.5 to $4.2 \mathrm{wt} \%)$ are at the lower limit values from other rivers $(1.9 \pm 1.0 \mathrm{wt}$. \%). Due to their high erodibility, badlands are responsible for a significant dilution of the POC contents in the Durance and Rhône River sediments. At the event scale, extreme floods can annually transport more than one third of the POC flux delivered to the Gulf of Lion (14 Gg in several days in November 2011) with a strong probable contribution from badlands in the organic petrogenic counterpart. If the occurrence of extreme events increases in the foreseeable future for the SPM, most of the POC

flux would reach the Mediterranean Sea in several days (Scoccimarro et al., 2016).

\section{3 pPOC from badlands: importance, contribution and nature}

Considering the bare badlands surfaces within the Durance catchment and a pPOC flux of $4.5 \mathrm{Gg} \mathrm{yr}^{-1}$, badlands yield about $26 \mathrm{Mg} \mathrm{km}^{-2} \mathrm{yr}^{-1}$. This yield is remarkable compared with those of the Durance and the Rhône rivers both close to $0.4 \mathrm{Mg} \mathrm{km}-2$ $\mathrm{yr}^{-1}$. pPOC flux from badlands accounts for more than $73 \%$ of the pPOC exported each year by the Durance River and $12 \%$ of the pPOC delivered to the Mediterranean Sea by the Rhône River, highlighting that these surfaces are hot spots for their contributions of pPOC (fig. 7D).

Since the other pPOC sources of the Rhône River are unknown and considering the lower pPOC content of the SPM samples of the Rhône River compared to that of the 
badlands, it is reasonable to state that the other sedimentary rocks may have lower pPOC content than the marls. Due to the large size of the Rhône catchment, it is difficult to accurately predict which lithology could be a significant candidate to this petrogenic flux. Seeking highly erodible sedimentary rocks outcropping within other major and alpine tributaries, such as the Isère River, could be a pertinent option. Other tributaries draining the Massif Central and Cevennes ranges (e.g. Ardèche River), mainly composed of magmatic and metamorphic rocks, and the Saone River draining some lowlands area, would likely not contribute significantly to the SPM flux of the Rhône River (Sadaoui et al., 2016), and would probably not hold areas of potentially large pPOC contributions. By contrast, other Mesozoic black marls and molasses outcropping along the external alpine range (Agard and Lemoine, 2003), could be considered as more conceivable candidates. Unpublished data on these marls reveal an intense weathering with lower TOC content ( 0.20 wt. \%), while molasses are rather devoid ( 0.10 wt \%) of TOC.

The nature of this pPOC would consist in refractory organic fraction mainly constituted of graphitic carbon, an ultimate state of thermal evolution of kerogen and originating from sedimentary or metamorphic rocks (Cathalot et al., 2013). These authors have reported that the graphitic POC content (considered as PPOC) would reach 0.34 wt. \%, close to the weighted value calculated in this study $(0.31$ wt. \%) with, however, a pPOC / POC ratio of 0.18 significantly lower than that modelled in this study. Is it possible that the pPOC from the badlands could be categorized as graphitic POC? This question requires further study, but regarding the moderate to high thermal evolution degree reached by the OM from these badlands (Copard et al., 2006, Graz et al., 2011), the OM could be retrieved after the heavy treatment applied to extract the refractory OM (Cathalot et al., 2013). 


\subsection{PPOC at the regional and global scale and the badlands contribution}

In the Mediterranean region, PPOC fluxes had not previously been documented except for the Rhône River, for which the pPOC flux was indirectly assessed using the POC yield of an instrumented badlands catchment (Graz et al., (2012). The comparison of our findings to those reported in the literature, and more specifically the ratio PPOC / POC compiled for some worldwide catchments (Galy et al., 2015, supp. material), reveals that our calculated and weighted ratio are rather high, especially for the badlands and the Durance River (fig. 8). Indeed, such high ratios are found for rivers classified as small mountainous river systems (SMRs, Leithold et al., 2006) draining active tectonic surfaces as in New Zealand (e.g. Waiaipu, 0.66), in Taiwan (e.g. Langyang, 0.70) or in California (e.g. Eel, 0.48, Santa Clara, 0.40). If badlands surfaces provide a high ratio (0.93), the Durance River exhibits a comparable significant ratio (0.49) although this river is not considered to drain an active tectonic surface (moderate seismicity) nor developed in the vicinity of an active margin. Clearly, this high ratio finds its origin in the occurrence of the badlands outcrops. Nadal-Romero et al. (2011) demonstrated that a small surface of bare badlands may increase the sediments yield by a factor of 7 to 8 for the Mediterranean catchment with a surface area over $10^{4}$ ha. In that sense, factors applied to the sediments should also be verified for the PPOC content, but this should be moderated by the TOC content of rocks constituting these badlands and by other parameters regulating the transit time in the catchment. However, common characteristics can be found between the Durance River and these SMRs have a very short transit time during sediments transport (e.g., Blair et al., 2003) coupled with a low Ts50 value (Meybeck et al., 2003). 
The Rhône River is a significant conveyor of ageing organic carbon to the Mediterranean marine environments (fig. 8). The calculated and weighted pPOC / POC ratio is in the same order of magnitude than the upper Yukon River $(0.22$, 0.23), the Beni River, a major tributary of the Amazon River draining the eastern part of the Andean range (0.34) and the Narayani River, draining the southern part of the Himalayan range and considered as a one of the major tributary of the GangeBrahmaputra River (0.31).

Regarding its continental shelf, the Rhone River is a River-dominated Ocean Margin (RiOMar, e.g., Cathalot et al., 2013) for which sediment and nutrient exports significantly impact the biogeochemical ocean cycles (Hedges and Keil, 1995, Bianchi and Allisson, 2009). It is currently accepted that these RiOMars transport large amounts of POC towards the ocean, primarily in the form of $\mathrm{rPOC}$, as seen for the Amazon, Mississippi or Ganges-Brahmaputra rivers characterised by low pPOC / POC ratios $(<0.08$, fig. 8$)$; and transporting significant amounts of aged dissolved OC (e.g., Mississippi: Raymond and Bauer, 2001). These low ratios are strongly dependent of the size of the catchment, but even for rivers with a catchment sizes comparable to that of the Rhône River, the ratio is generally lower than 0.17 (e.g. Fly and Fraser rivers, fig. 8). Hitherto, pPOC export to the oceans has therefore been primarily attributed to rivers classified as small mountainous river systems (Leithold et al., 2006, Petsch, 2014).

We demonstrated here that these RiOMars could also export significantly petrogenic $\mathrm{OM}$ in particulate forms to the marine environments, as shown for the Yangtze River (0.47, fig. 8). For this river, the main pPOC source consists in carbonate interlayed black shales formation ( $\mathrm{Li}$ et al., 2015), probably developing gullies and subjected to debris flow on steep slope as seen in the Upper Yangtze River (Wang et al., 2007). 
The most likely hypothesis explaining the ratio of 0.26 found for the Rhône River is the occurrence of badlands, also subjected to gullying, in its catchment and the fact that this river exhibits a rapid transit time ( $\mathrm{TS}_{50}$ lower than $4.5 \%$, section 5.2 ). Essentially, this pPOC export capacity is linked to several major factors i) the occurrence of eroded and erodible outcropped sedimentary rocks, ii) climatic conditions, iii) a relatively short residence time of sediments in the river minimizing the intensity of weathering, and iv) an intrinsic resistance of pPOC towards (sub)surface processes depending on the nature and origin of the $\mathrm{OM}$ (e.g., OM types classically used in petroleum studies, e.g., Van Krevelen, 1993).

Our study confirms that the RiOMar could, at least regionally and with the occurrence of sedimentary rocks with high erosion rates, such as those forming badlands, be significant in the pPOC transfer and its recycling to the oceans.

\subsection{Towards a POC budget in the Gulf of Lion}

Among concerns about the origin and the flux of POC transported by rivers is the $\mathrm{C}$ balance where the $\mathrm{C}$ flux from rivers to oceans represents a lateral $\mathrm{C}$ pump. This lateral C flux can reach $20 \%$ of the net primary production in European continental surfaces, and it could be a sink if $C$ storage occurs in the sediments (Ciais et al., 2008). Accordingly, it is important to determine the contribution of each OC continental reservoir involved in these lateral fluxes in order to define their role as a source or sink.

The POC export from the Rhône River to the Gulf of Lion is less than $10 \%$ of the POC from the net marine primary productivity (Durrieu de Mardon et al., 2000), but its origin remains contentious. For example, Sempéré et al. (2000) have suggested 
that more than $80 \%$ of the POC content between 1987 and 1996 was refractory OC without any petrogenic contribution (Ludwig et al., 1996, Sempéré et al., 2000). In Cathalot et al. (2013), the petrogenic contribution is mixed with the combustion residues of terrestrial OM (black carbon), without the ability to determine the pPOC content in this mixture. In our study, based on ${ }^{14} \mathrm{C}$ activities, we claim that almost one quarter of this riverine POC exported by the Rhône River could have a petrogenic origin. However, uncertainties remain about its future in the marine environment. Past optical observations of deltaic sediments have shown that the pPOC was essentially composed of bituminous coals, anthracites and meta-anthracites (Gadel and Ragot, 1973). More recently, it was shown that the POC stored in the pro-delta sediments has a soil origin $(90 \%)$, while less than $5 \%$ is related to the refractory OM (i.e., pPOC and black carbon, Cathalot et al., 2013). In this study, this refractory contribution tends to increase up to $40 \%$ in distal sediments with a significant decrease in the pPOC fraction due to the black carbon / graphitic POC. These findings validate the classical fact that the higher the thermal stress previously recorded by kerogen (bearing $\mathrm{pPOC}$ ) or black carbon is, the stronger the preservation of this POC in marine sediments. If we consider that badlands are one of the main sources of pPOC at the interface of the Rhône catchment / Gulf of Lion, could the pPOC from the badlands be sufficiently thermally evolved to escape from any processes in the marine sediments? According to the published geochemical data of OM from these badlands (Copard et al., 2006, Graz et al., 2011), this hypothesis is fully justified but requires further study of the different POC origins preserved in the deltaic sediments. 


\section{Conclusions \& Perspectives}

We revisited the Rhône River POC flux, one of the most important sediment conveyors to the Mediterranean Sea, with one quarter of this flux associated with pPOC. Despite representing only $0.2 \%$ of the Rhône catchment area, bare badlands outcropping in the Durance catchment could provide $12 \%$ of the petrogenic POC, $3 \%$ of the POC flux and $14 \%$ of the SPM flux delivered to the Mediterranean Sea. This contribution should be considered as a minimum since badlands also outcrop within the catchment of other tributaries, especially the Isère River. At the hydrological event scale, such contributions could significantly increase, as seen in November 2011, since these extreme flood events could be increasingly common in the future decades around the Mediterranean area.

Accordingly, the badlands are considered as a hot spot of pPOC recycling in the Rhône catchment, but what about at a regional and global scale? Lacking a precise total surface area of these outcropping badlands around the Mediterranean area, and based on their high erosion rate, it is likely that these badlands are one of the major sources of sediments and pPOC in the Mediterranean rivers. At a global scale, we could claim that these specific geoforms occurring in continental surfaces are able to deliver a significant amount of sediments and pPOC to the rivers. Consequently, as seen for SMRs, RiOMars containing badlands in their catchment could significantly contribute to the pPOC recycling in continental surfaces.

\section{Acknowledgments}

LABEX DRIIHM, OHM "Vallée du Rhône" and the French National research project CNRS-INSU-EC2CO (DEMON project) have supported this work. Data were 
provided by (i) "MOOSE: Mediterranean Oceanic Observing System on Environment" with the support of Agence de l'Eau Rhône-Méditerranée-Corse, for the parameters from SORA station, (ii) EdF for the water flow and SPM flux of the Durance River, (iii) IRSN for the ${ }^{14} \mathrm{C}$ activity of some SPM and FS samples. This work has also benefited from samples and data from the French Critical Zone observatory of Draix - Bléone (SOERE RBV) and the Rhône sediment Observatory (OSR) program belonging to the LTER-France (Zone Atelier Bassin du Rhône). We also warmly thank R. Booth for reviewing this manuscript.

\section{References}

Agard P, Lemoine P. 2003. Visages des Alpes: structure et évolution géodynamique. Commission for the geological map of the world, 48p, ISBN: 2-9517181-1-X.

Berner RA. 1982. Burial of organic carbon and pyrite sulfur in the modern ocean: its geochemical and environmental significance. American Journal of Science 282: $451-473$.

Berner RA. 1989. Biogeochemical cycles of carbon and sulfur and their effect on atmospheric oxygen over Phanerozoic time. Global and Planetary Change 1: 97122.

Bertier C, Bouchard JP. 2007. Gestion sédimentaire à l'échelle d'un bassin versant : la Durance, oral presented at Colloque Hydroécologie EdF, 19-20 November, Tours, France.

Bianchi TS, Allisson MA. 2009. Large-river delta-front estuaries as natural "recorders" of global environmental change. Proceeding of the National Academy of Sciences 10, 20: 8085-8092. DOI:10.1073/pnas.0812878106. 
Blair NE, Leithold EL, Ford ST, Peeler KA, Holmes JC, Perkey DW. 2003. The persistence of memory: The fate of ancient sedimentary organic carbon in a modern sedimentary system. Geochimica et Cosmochimica Acta 67: 63-73. DOI:10.1016/S0016-7037(02)01043-8.

Blair NE, Leithold EL, Brackley H, Trustrum N, Page M, Childress L. 2010. Terrestrial sources and export of particulate organic carbon in the Waipaoa sedimentary system: Problems, progress and processes. Marine Geology 270: 108-118. DOI:10.1016/j.margeo.2009.10.016

Brochot S. 1993. Etude de la représentativité des bassins versants expérimentaux de Draix, in: Erosion de badlands dans le système Durance - Etang de Berre, Rep. 93/0443, p. 81, Cemagref and Agence de l'Eau Rhône, Méditerranée, Corse.

Bryan RB, Campbell IA. 1986. Runoff and sediment discharge in a semiarid ephemeral drainage basin, In: Geomorphology and Land management, $\mathrm{O}$. Slaymaker and D. Balteanu (eds), 121-143, Zeitschrift für Geomorphologie, Springer, Berlin..

Cathalot C, Rabouille C, Tisnérat-Laborde N, Toussaint F, Kerhervé P, Buscail R, Loftis K, Sun MY, Tronczynski J, Azoury S, Lansard B, Treignier C, Pastor L, Tesi T. 2013. The fate of river organic carbon in coastal areas: A study in the Rhône River delta using multiple isotopic $\left(\square^{13} \mathrm{C}, \square^{14} \mathrm{C}\right.$ ) and organic tracers. Geochimica et Cosmochimica Acta 118: 33-55. DOI: org/10.1016/j.gca.2013.05.001.

Chorley RJ, Schumm SA, Sungden DE. 1984. Geomorphology, Methuen, New York. Ciais P, Borges AV, Abril G, Meybeck M, Folberth G, Hauglustaine D, Janssens IA. 2006. The impact of lateral carbon fluxes on the European carbon balance. Biogeosciences 5: 1259-1271. DOI:10.5194/bg-5-1259-2008. 
Copard Y, Di-Giovanni C, Martaud T, Albéric P, Ollivier JE. 2006. Using Rock-Eval 6 pyrolysis for tracking fossil organic carbon in modern environments: implications for the roles of erosion and weathering. Earth Surface Processes and Landforms 31: 135-153. DOI:10.1002/esp.1319.

Copard Y, Amiotte-Suchet P, Di-Giovanni C. 2007. Storage and release of fossil organic carbon related to weathering of sedimentary rocks. Earth and Planetary Science Letters 258: 345-357. DOI:10.1016/j.epsl.2007.03.048.

Delmas M, Cerdan O, Cheviron B, Mouchel JM, Eyrolle F. 2012. Sediment export from French rivers to the sea. Earth Surface Processes and Landforms 37: 754-762. DOI:10.1002/esp.3219.

Durrieu de Mardon X, Abassi A, Heussner S, Monaco A, Aloisi JC, Radakovitch O, Giresse P, Buscail R, Kerhervé P. 2000. Particulate matter and organic carbon budgets for the Gulf of Lions (NW Mediterranean). Oceanologica Acta 23, 6: 717730.

Dürr HH, Meybeck M, Dürr SH. 2005. Lithologic composition of the Earth's continental surfaces derived from a new digital map emphasizing riverine material transfer. Global Biogeochemical Cycles 19. DOI:10.1029/2005GB002515

Eyrolle F, Radakovitch O, Raimbault P, Charmasson S, Antonelli C, Ferrand E, Aubert D, Raccasi G, Jacquet S, Gurriaran R. 2012. Consequences of hydrological events on the delivery of suspended sediment and associated radionuclides from the Rhône River to the Mediterranean Sea. Journal of Soils and Sediments 12: 14791495. DOI:10.1007/s11368-012-0575-0

Eyrolle-Boyer F, Antonelli C, Renaud P, Tournieux D. 2015. Origins and trend of radionuclides within the Rhône River over the last decades. Radioprotection 50, 1: 27-34. DOI:10.1051/radiopro/2014022. 
Fournier L. 2004. Modélisation de la production des apports sédimentaires dans le bassin versant de la Durance, M.S. thesis, DEA Hydrologie, Hydrogéologie, Géostatistique et Géochimie, Univ. Pierre et Marie Curie, Paris, France.

Gadel F, Ragot JP. 1973. Sur l'allochtonie de la fraction organique particulaire des dépôts quaternaires récents du Golfe du Lion, in Adv. Organic Geochemistry edited by B. Tissot and F. Bienner, 21: 619-628.

Gallart F, Marignagni M, Perez-Gallego N, Santi E, Maccherini S. 2013. Thirty years of studies on badlands, from physical to vegetational approaches. A succinct review. CATENA 106: 4-11. DOI:10.1016/j.catena.2012.02.008.

Galy V, Beyssac O, France-Lanord C, Eglinton TI. 2008. Recycling of graphite during Himalayan erosion: a geological stabilization of carbon in the crust. Science 322: 943-945. DOI:10.1126/science.1161408.

Galy V, Eglinton T. 2011. Protracted storage of biospheric carbon in the GangesBrahmaputra basin. Nature Geoscience 4: 843-847. DOI:10.1038/ngeo1293.

Galy V, Peucker-Ehrenbrink B, Eglinton T. 2015. Global carbon export from the terrestrial biosphere controlled by erosion. Nature 521: 204-207. DOI:10.1038/nature14400.

Graz Y. 2009. Production et devenir du carbone organique fossile libéré par les altérations mécaniques et chimiques des formations marneuses : exemple des "terres noires" des bassins versants expérimentaux de Draix (Alpes de Haute Provence, France), Doctoral thesis, Institut des Sciences de la Terre d'Orléans, Univ. of Orléans, France

Graz Y, Di-Giovanni C, Copard Y, Elie M, Faure P, Laggoun-Défarge F, Leveque J, Michels R, Ollivier JE. 2011. Fossil organic matter occurrence in modern 
environments : optical, geochemical and isotopical evidences. Applied Geochemistry 26: 1302-1314. DOI:10.1016/j.apgeochem.2011.05.004.

Graz Y, Di Giovanni C, Copard Y, Mathys N, Cras A, Marc V. 2012. Annual mechanical and chemical fluxes of fossil organic carbon exported by marly badlands areas: Example of the Draix experimental watersheds (Alpes de Haute Provence, France). Earth Surface Processes and Landforms 37: 1263-1271. DOI:10.1002/esp.3232.

Hedges JI, Keil RG. 1995. Sedimentary organic matter preservation: an assessment and speculative synthesis. Marine Chemistry 49: 81-115.

Hilton RG. 2017. Climate regulates the erosional carbon export from the terrestrial biosphere. Geomorphology 277: 118-132. DOI: org/10.1016/j.geomorph.2016.03.028 Hilton RG, Galy A, Hovius N, Horng MJ. 2011. Efficient transport of fossil organic carbon to the ocean by steep mountain rivers: an orogenic carbon sequestration mechanism. Geology 39: 71-74. DOI: 10.1130/G31352.1.

Kao SJ, Liu KK. 1996. Particulate organic carbon export from a subtropical mountainous river (Lanyang Hsi) in Taiwan. Limnology and Oceanography 41: $1749-1757$.

Kerckhove C, Barfety JC, Lemoine M. 1980. Carte Géologique de la France à 1/250000, n³5, Gap, BRGM édition, Orléans, France.

Lafargue E, Marquis F, Pillot D. 1998. Rock-Eval 6 applications in hydrocarbons exploration, production and soil contamination studies. Revue de I'Institut Français du Pétrole 53, 4: 421-437.

Leithold EL, Blair NE, Perkey DW. 2006. Geomorphologic controls on the age of particulate organic carbon from small mountainous and upland rivers. Global Biogeochemical Cycles 20, GB3022. DOI:10.1029/2005GB002677. 
Li G, Wang XT, Yang Z, Mao C, West AJ, Ji J. 2015. Dam-triggered organic carbon sequestration makes the Changjiang (Yantze) river basin (China) a significant carbon sink. Journal of Geophysical Research: Biogeosciences 120: 39-53, DOI: 10.1002/2014JG002646.

Ludwig W, Probst JL, Kempe S. 1996. Predicting the oceanic input of organic carbon by continental erosion. Global Biogeochemical Cycles 10, 1: 23-41.

Ludwig W, Dumont E, Meybeck M, Heussner S. 2009. River discharges of water and nutrients to the Mediterranean Sea: Major drivers for ecosystem changes during past and future decades? Progress in Oceanography 80: 199-217. DOI:10.1016/j.pocean.2009.02.001.

Mathys N, Brochot S, Meunier M, Richard D. 2003. Erosion quantification in the small marly experimental catchments of Draix (Alpes de Haute Provence, France), calibration of the ETC rainfall-runoff-erosion model. CATENA 50: 527-548. DOI:10.1016/S0341-8162(02)00122-4.

Meybeck M. 1993. C, N and $\mathrm{P}$ in rivers. in Interaction of $\mathrm{C}, \mathrm{N}, \mathrm{P}$ and $\mathrm{S}$, Biogeochemical Cycles on Global Change, edited by R. Wollast, F. T. McKenzie, and L. Chou, pp. 163-193. Springer, Berlin.

Meybeck M, Laroche L, Dürr HH, Syvitski JPM. 2003. Global variability of daily total suspended solids and their fluxes in river. Global and Planetary Change 39: 65-93. DOI: 10.1016/S0921-8181(03)00018-3.

Milliman JD, Farnsworth KL. 2011. Human activities and their impact, in: River discharge to the coastal ocean: a global synthesis, 115-161, Cambridge University Press, Cambridge, UK.

Mook WG, Van der Plicht J. 1999. Report ${ }^{14} \mathrm{C}$ activities and concentrations. Radiocarbon 41: 227-239. 
Nadal-Romero E, Martínez-Murillo JF, Vanmaercke M, Poesen J. 2011. Scaledependency of sediment yield from badland areas in Mediterranean environments. Progress in Physical Geography 35(3): 297-332. DOI:10.1177/0309133311400330. Navratil O, Evrard O, Esteves M, Ayrault S, Lefèvre I, Legout C, Reyss JL, Gratiot N, Nemery J, Mathys N, Poirel A, Bonté P. 2012. Core-derived historical records of suspended sediment origin in a mesoscale mountainous catchment: the River Bléone, French Alps. Journal of Soils and Sediments 12: 1463-1478. DOl: $10.1007 / \mathrm{s} 11368-012-0565-2$.

Némery J, Mano V, Coynel A, Etcheber H, Moatar F, Meybeck M, Belleudy P, Poirel A. 2012. Carbon and suspended sediment transport in an impounded alpine river (Isère, France), Hydrological Processes 27: 2489-2508. DOI: 10.1002/hyp.9387.

Ollivier P, Hamelin B, Radakovitch O. 2010. Seasonal variations of physical and chemical erosion: a three-year survey of the Rhone River (France). Geochimica et Cosmochimica Acta 74: 907-927. DOI:org/10.1016/j.gca.2009.10.037.

Petsch ST. 2014. Weathering of Organic Carbon. In: Treatise on Geochemistry, Second Edition, vol. 12, edited by H.D. Holland and K.K. Turekian, pp. 217-238, Elsevier, Oxford.

Poirel A. 2009. Mesures des transports solides en suspension dans la Durance sur cent-cinquante ans (1857-2007): liaisons avec les opérations de restauration écologique intervenues à l'échelle du bassin versant de la rivière. Ingénieries, $\mathrm{n}^{\circ}$ special, 85-98.

Poirel A. 1998. Solid discharge modeling for the Isère River near Grenoble, relations with hydroclimatology. La Houille Blanche 5/6: 138-145. DOI: 10.1051/lhb/1998074.

Pont D, Simonnet JP, Walter AV. 2002. Medium-term changes in suspended sediment delivery to the ocean: consequences of catchment heterogeneity and river 
management (Rhône river, France). Estuarine Coastal and Shelf Science 54: 1-18. DOI:10.1006/ecss.2001.0829.

Raymond PA, Bauer JE. 2001. Riverine export of aged terrestrial organic matter to the North Atlantic Ocean. Nature 409: 497-500.

Rey F, Abraham A, Gallicher-Lavanne C, Burylo M, Eugène RE, Mermin E, Puech C. 2007. Etude de la faisabilité d'une opération de réhabilitation écologique de ravines marneuses érodées pour la rétention durable des sédiments à l'échelle du bassin versant de la Durance. In: Rapport d'étude de l'Action 8 "Expérimenter le contrôle de l'érosion des versants de marnes noires" du Plan Durance Multi-Usages, edited by Cemagref.

Rouire J, Autran A, Bodelle J. 1979a. Carte Géologique de la France au 1/250000, 40, Nice, BRGM édition, Orléans, France.

Rouire J, Blanc JJ, L'Homer A. 1979b. Carte Géologique de la France au 1/250000, 39, Marseille, BRGM édition, Orléans, France.

Rouire J, Berger G, Gidon M. 1980. Carte Géologique de la France au 1/250000, 34, Valence, BRGM édition, Orléans, France.

Rolland B. 2006. Transfert des radionucléides artificiels par voie fluvial : conséquences sur les stocks sédimentaires rhodaniens et les exports vers la Méditerranée. Doctoral thesis, Univ. Aix-Marseille, France.

Ronov AB, Yaroshevsky AA. 1976. A new model for the chemical structure of the Earth crust. Geochemistry International 13: 1761-1795.

Roose E, Meybeck M, Lal R, Feller C. 2006. Soil Erosion and Carbon Dynamics: conclusions and perspectives. In: Erosion and carbon dynamics, E. J. Roose, R. Lal, C. Feller, B. Barthes, B. A. Stewart (eds), chapter 21, 395-402, Taylor and Francis, Boca Raton, Florida, USA. 
Sackett WM, Poag CW, Eadie BJ. 1974. Kerogen recycling in the Ross Sea, Antarctica. Science 185: 1045-1047.

Sadaoui M, Ludwig W, Bourrin F, Raimbault P. 2016. Controls, budgets and variability of riverine sediment fluxes to the Gulf of Lions (NW Mediterranean Sea). Journal of Hydrology 540: 1002-1015. DOI:10.1016/j.jhydrol.2016.07.012

Sarmiento J, Gruber N. 2006. In: Ocean Biogeochemical Dynamics edited by J. Sarmiento and N. Gruber, pp. 392-453, Univ. Press, Princeton.

Scoccimarro E, Gualdi S, Bellucci A, Zampieri M, Navarra A. 2016. Heavy precipitation events over the Euro-Mediterranean region in a warmer climate: results from CMIP5 models, Reg. Environ. Change, 16, 595-602, doi: 10.1007/s10113-0140712-y.

Sempéré R, Charrière B, Van Wambeke F, Cauwet G. 2000. Carbon inputs of the Rhône River to the Mediterranean Sea: Biogeochemical implications, Global Biogeochemical Cycles 14, 2: 669-681.

Van Krevelen DW. 1993. Coal: typology, chemistry, physics, constitution, 3rd edition, Elsevier, Amsterdam.

Wang ZY, Li Y, He Y. 2007. Sediment budget of the Yangtze River. Water Resources Research 43: W04401. DOI: 10.1029/2006WR005012.

Zebracki M, Eyrolle-Boyer F, Evrard O, Claval D, Mourier B, Gairoard S, Cagnat X, Antonelli C. 2015. Tracing the origin of suspended sediment in a large Mediterranean river by combining continuous river monitoring and measurement of artificial and natural radionuclides. Science of the Total Environment 502: 122-132. DOI:10.1016/j.scitotenv.2014.08.082. 


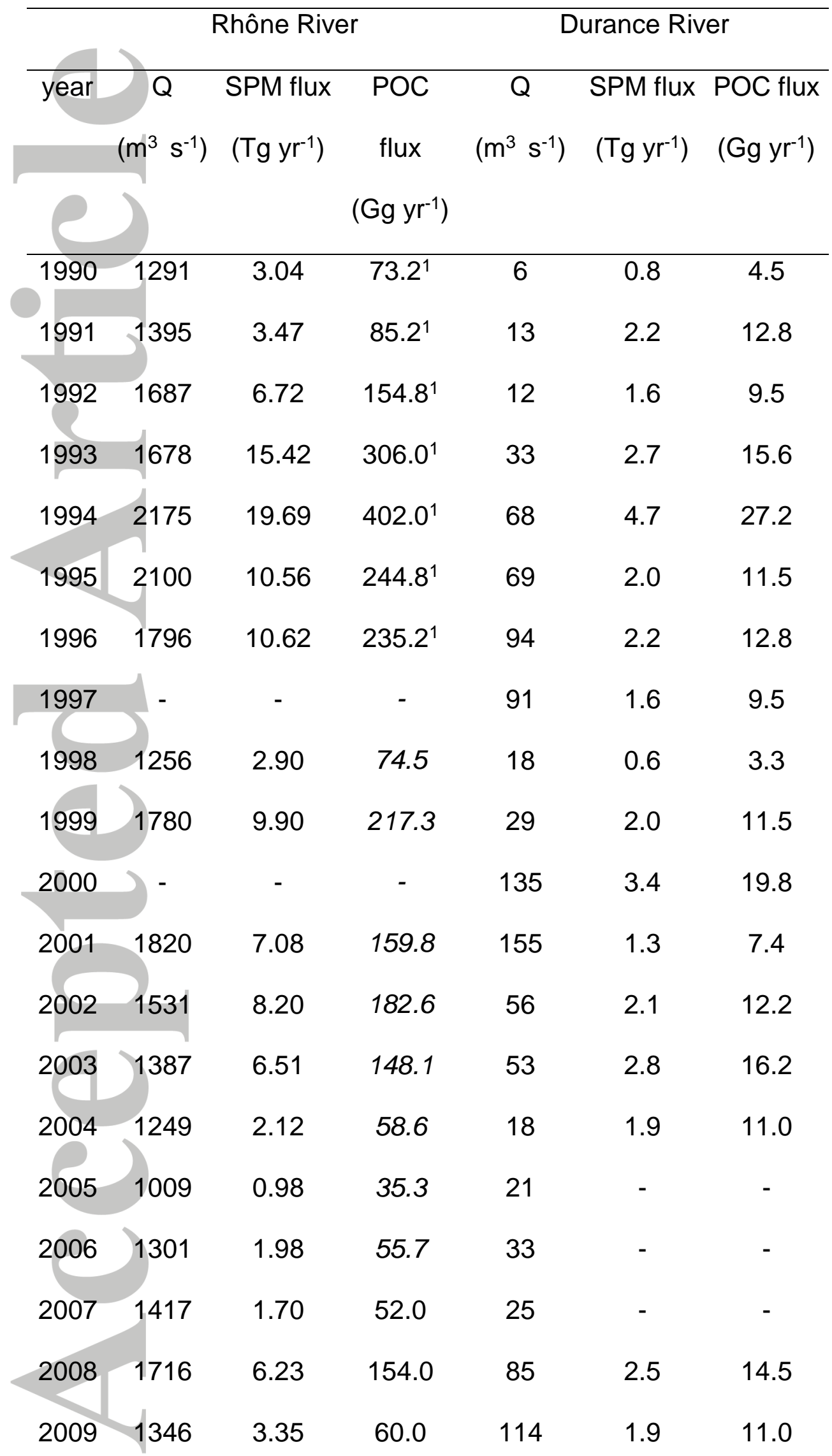




\begin{tabular}{rrrrrrc}
2010 & 1645 & 3.11 & 66.0 & 152 & 1.7 & 9.9 \\
2011 & 1230 & 2.50 & 39.0 & 80 & 1.9 & 11.1 \\
2012 & 1660 & 5.76 & 174.0 & 97 & 1.5 & 8.7 \\
2013 & 1970 & 8.43 & 222.0 & 172 & 3.5 & 20.3 \\
2014 & 1870 & 6.24 & 126.0 & 151 & 2.0 & 11.6 \\
\hline
\end{tabular}

table 1: yearly time serie data for water discharge (Q), SPM and POC fluxes for the Rhône and the Durance Rivers at SORA (Rhône) and downstream the Bonpas dam (Durance), (fig. 1). Origin and methodology for POC fluxes calculation are given in the text. For the Rhône River, calculated SPM and Q values between 2011-2014 are slightly different from the OSR database $(2.7,5.6,7.6$ and 5.8 Tg). For POC flux of the Rhône River: ${ }^{1}$ : values from Sempéré et al., (2000), italic values: modeled values (this work), other values: SOERE MOOSE database (this work). 


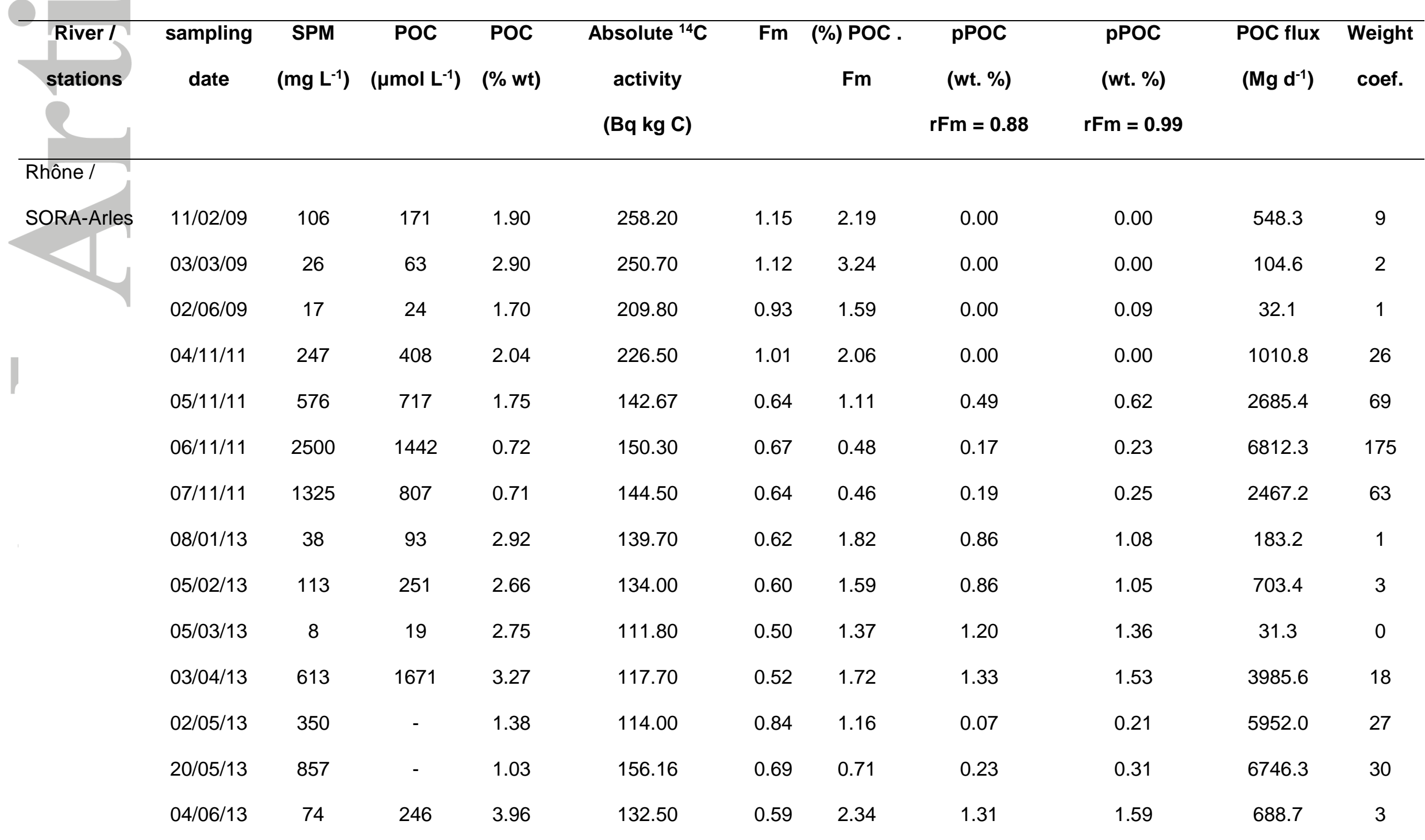




\begin{tabular}{|c|c|c|c|c|c|c|c|c|c|c|c|}
\hline \multirow{3}{*}{ (1) } & $02 / 07 / 13$ & 31 & 57 & 2.23 & 146.40 & 0.65 & 1.46 & 0.58 & 0.76 & 83.0 & 0 \\
\hline & 06/08/13 & 16 & 47 & 3.40 & 170.70 & 0.76 & 2.59 & 0.47 & 0.78 & 53.3 & 0 \\
\hline & $27 / 02 / 14$ & 99 & 205 & 2.49 & 196.50 & 0.88 & 2.18 & 0.02 & 0.28 & 573.1 & 5 \\
\hline \multicolumn{12}{|l|}{ Durance / } \\
\hline Mirabeau & $05 / 11 / 11$ & - & - & 0.56 & 118.80 & 0.53 & 0.30 & 0.22 & 0.26 & - & - \\
\hline 4 & $28 / 11 / 12$ & - & - & 0.56 & 119.59 & 0.53 & 0.30 & 0.22 & 0.26 & - & - \\
\hline FS & $15 / 11 / 12$ & - & - & 0.56 & 136.83 & 0.61 & 0.34 & 0.17 & 0.21 & - & - \\
\hline & $29 / 04 / 13$ & - & - & 0.55 & 116.63 & 0.52 & 0.29 & 0.22 & 0.26 & - & - \\
\hline & $29 / 11 / 12$ & - & - & 0.55 & - & - & - & - & - & - & - \\
\hline Draix & $12 / 07 / 06$ & 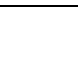 & & 0.56 & 15.71 & 0.07 & 0.04 & 0.52 & 0.52 & $\mathrm{nc}$ & 30 \\
\hline \multirow[t]{5}{*}{ Laval } & 08/09/06 & - & - & 0.62 & 13.69 & 0.06 & 0.04 & 0.58 & 0.58 & - & 30 \\
\hline & $20 / 10 / 06$ & - & - & 0.53 & 11.76 & 0.05 & 0.03 & 0.50 & 0.50 & - & 30 \\
\hline & 05/06/07 & - & - & 0.61 & 14.21 & 0.06 & 0.04 & 0.57 & 0.57 & - & 30 \\
\hline & $22 / 11 / 07$ & - & - & 0.48 & 11.16 & 0.05 & 0.02 & 0.45 & 0.46 & - & 30 \\
\hline & $20 / 11 / 06$ & - & - & 0.45 & 6.73 & 0.03 & 0.01 & 0.43 & 0.44 & - & 30 \\
\hline
\end{tabular}




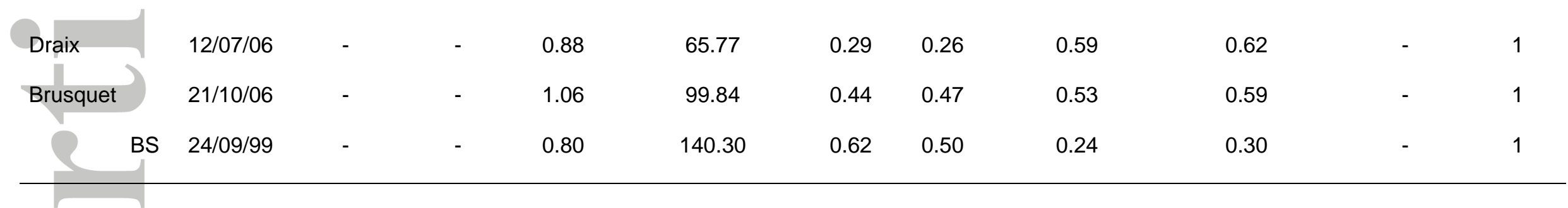

table 2: Main parameters of the studied samples (BS: bed sediment, FS: flood sediment, others: SPM), see text for the explanation and the use of each parameter.

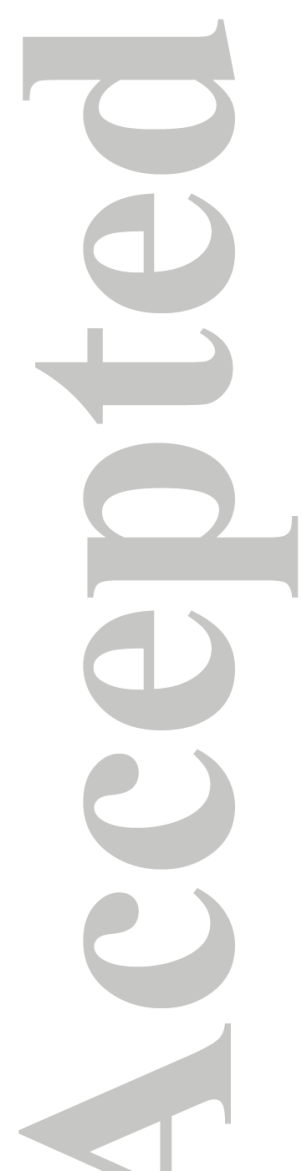




\begin{tabular}{|c|c|c|c|c|c|c|}
\hline year & $\begin{array}{l}\text { [POC] } \\
\text { leasures } \\
\text { (days) }\end{array}$ & $\begin{array}{c}\text { missing } \\
{[\mathrm{POC}](\%)}\end{array}$ & $\begin{array}{c}\mathrm{Q} \\
\text { measures } \\
\text { (days) }\end{array}$ & $\begin{array}{c}\text { missing } \\
\text { Q value } \\
(\%)\end{array}$ & $\begin{array}{c}\text { [SPM] } \\
\text { measures } \\
\text { (days) }\end{array}$ & $\begin{array}{c}\text { missing } \\
\text { [SPM] } \\
(\%)\end{array}$ \\
\hline 2005 & & & 231 & 36.7 & 231 & 36.7 \\
\hline 2006 & & & 323 & 11.5 & 323 & 11.5 \\
\hline 2007 & 322 & 11.8 & 322 & 11.8 & 322 & 11.8 \\
\hline 2008 & 348 & 4.9 & 350 & 4.4 & 350 & 4.4 \\
\hline 2009 & 179 & 51.0 & 342 & 6.3 & 342 & 6.3 \\
\hline 2010 & 320 & 12.3 & 336 & 7.9 & 336 & 7.9 \\
\hline 2011 & 310 & 15.1 & 365 & 0.0 & 325 & 11.0 \\
\hline 2012 & 308 & 15.8 & 366 & 0.0 & 342 & 6.3 \\
\hline 2013 & 325 & 11.0 & 365 & 0.0 & 340 & 6.8 \\
\hline 2014 & 245 & 32.9 & 350 & 4.1 & 277 & 24.1 \\
\hline
\end{tabular}




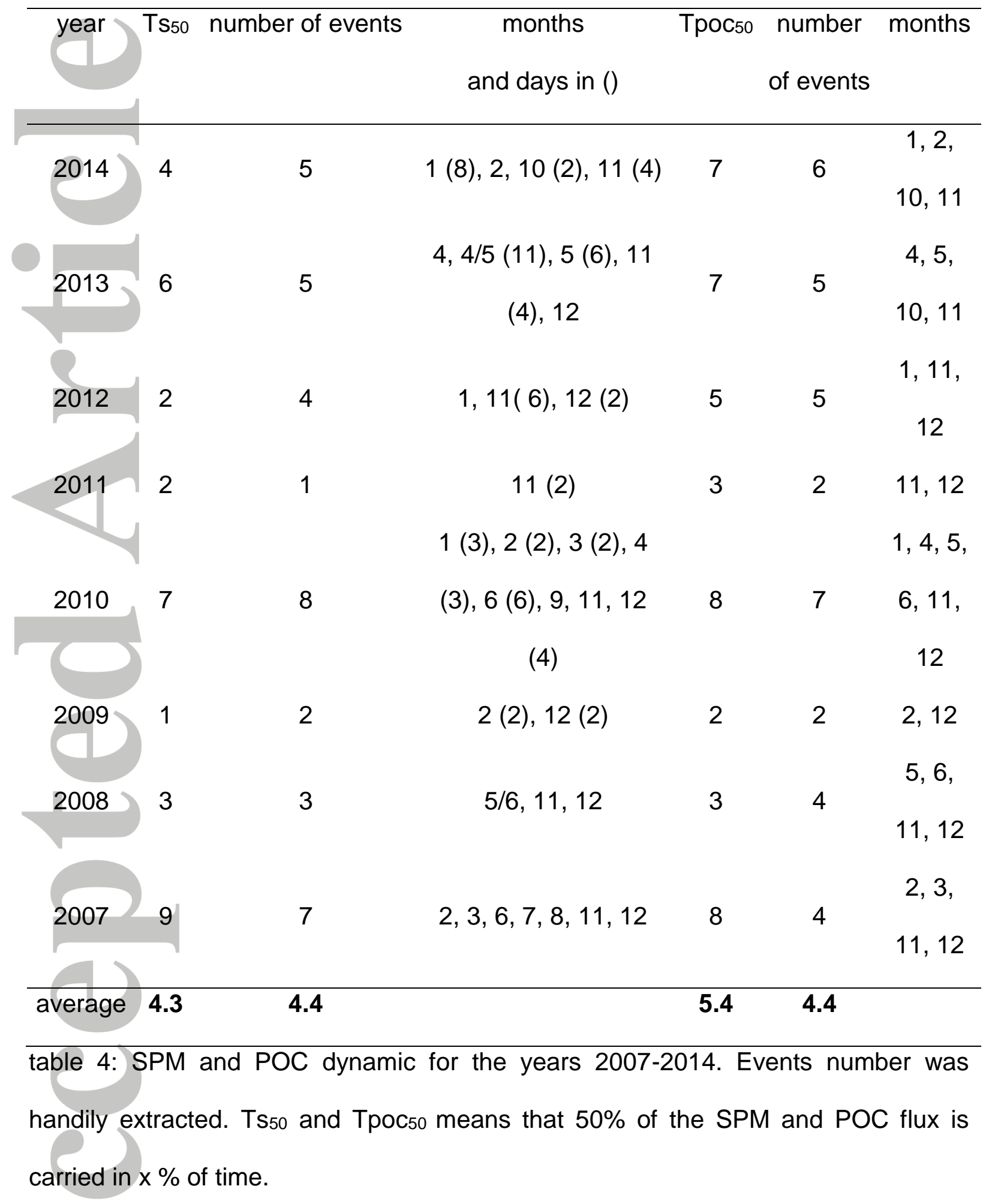




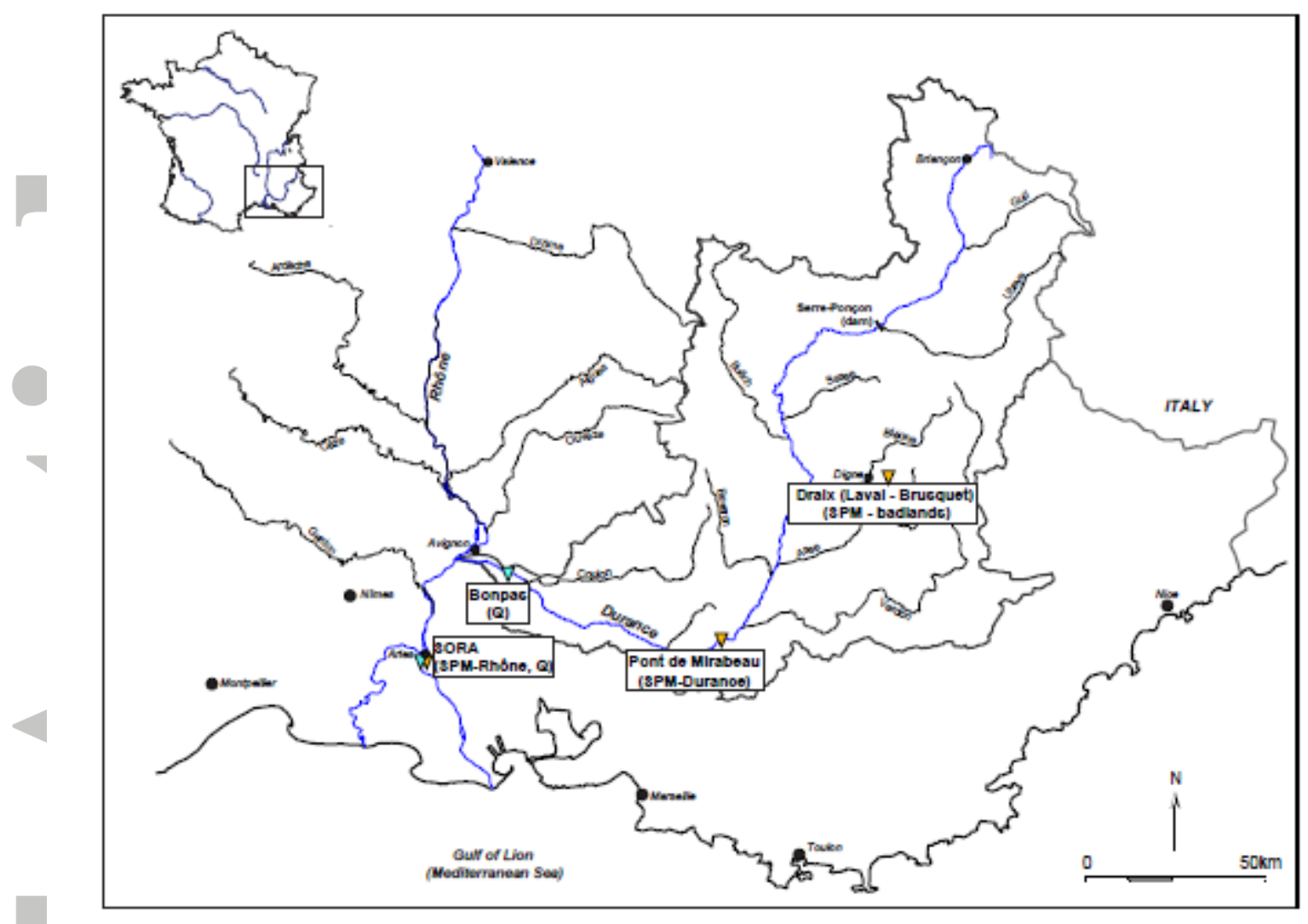

figure 1: Lower Rhône, Durance catchment and sampling locations. Orange triangle: SPM sampling at the station; blue triangle: water discharge estimated at the station. 

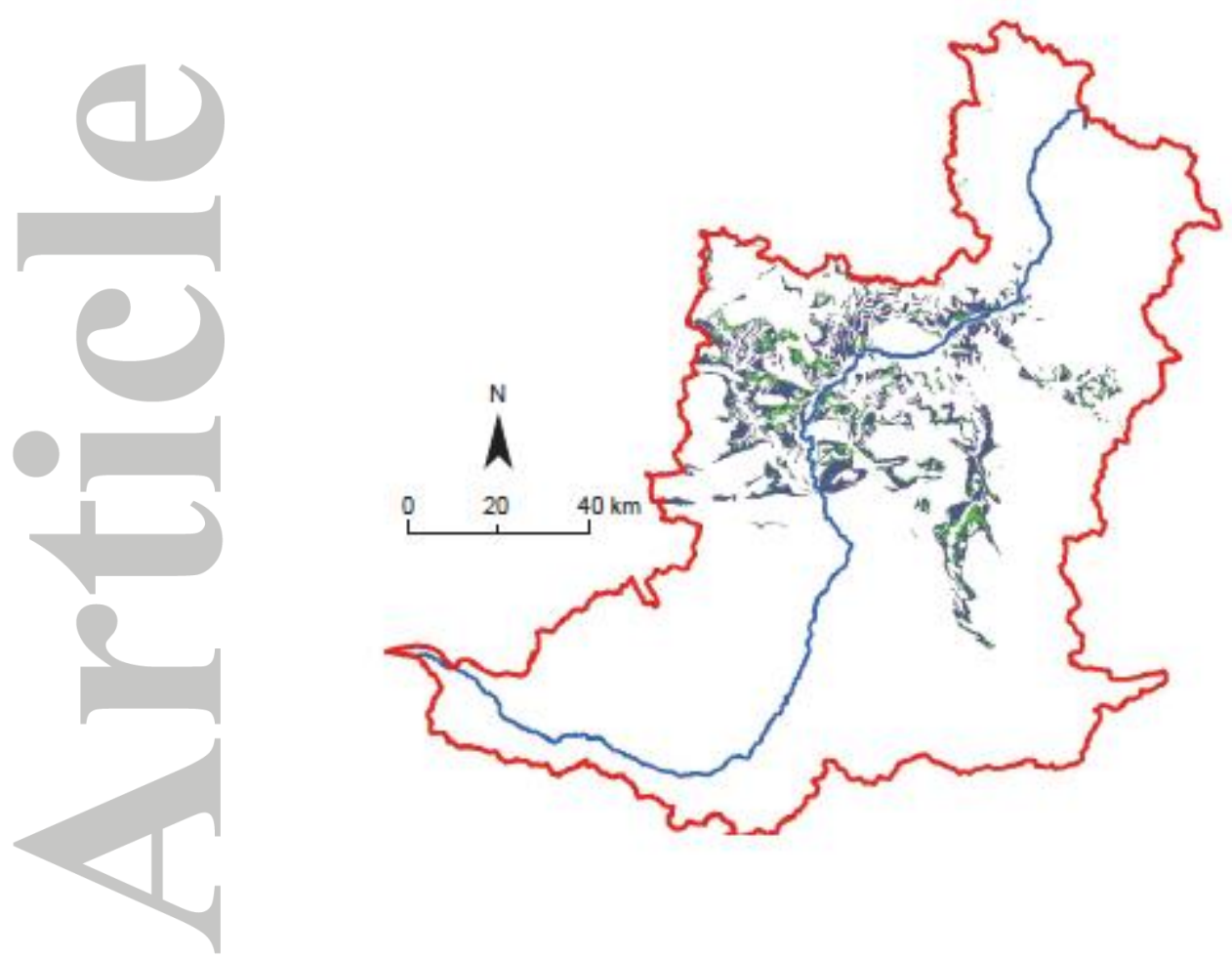

figure 2: badlands distribution within the Durance catchment given from geological map and Corine Land Cover. Blue: vegetalised badlands surfaces; green: barren badlands surfaces.

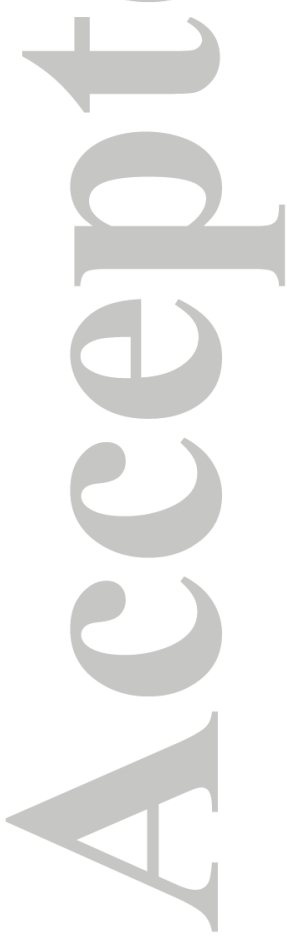



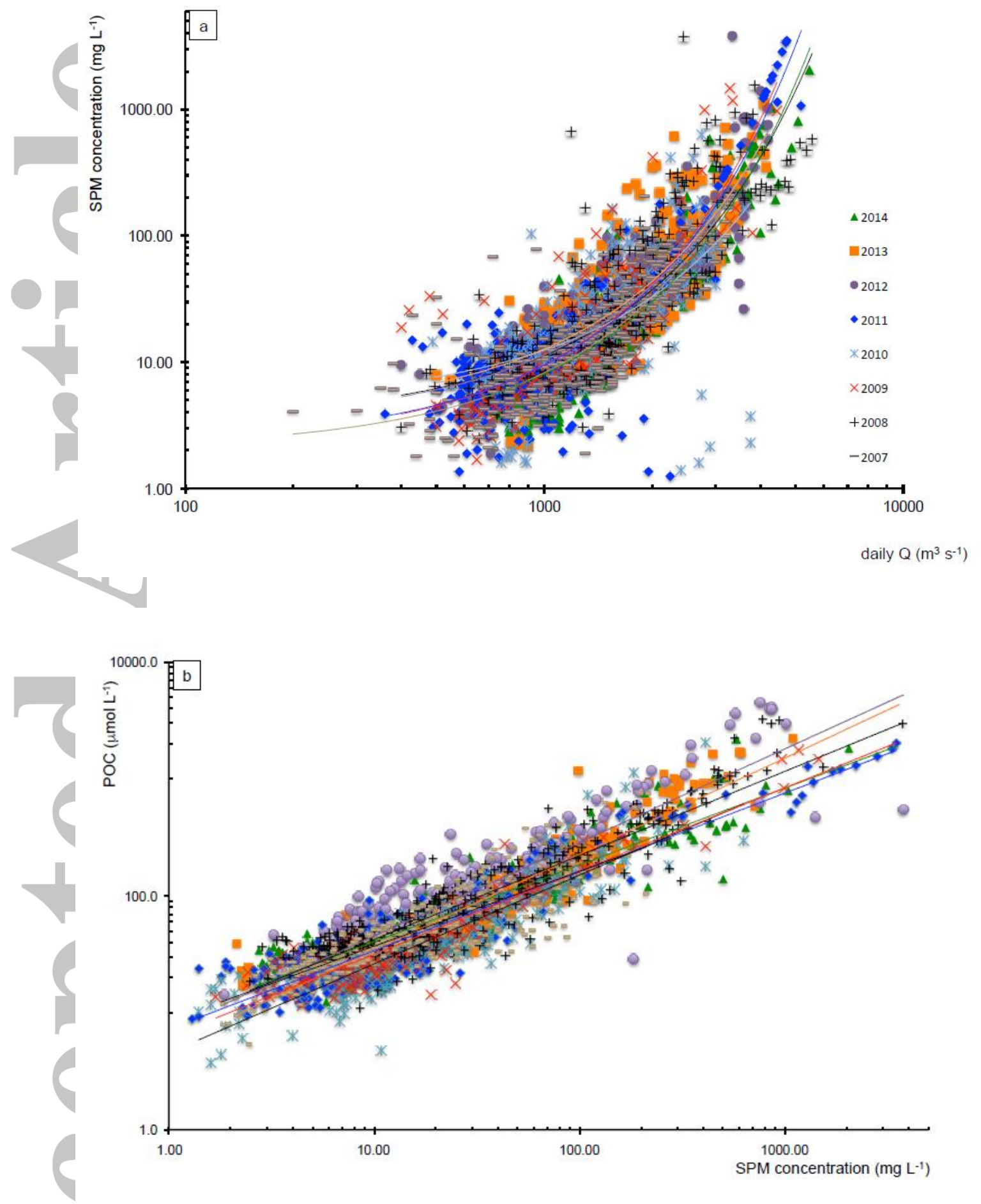

figure 3: relation (years 2007 to 2014) between (a) SPM concentrations and water discharge, (b) SPM concentrations and POC concentration at the station SORA. 

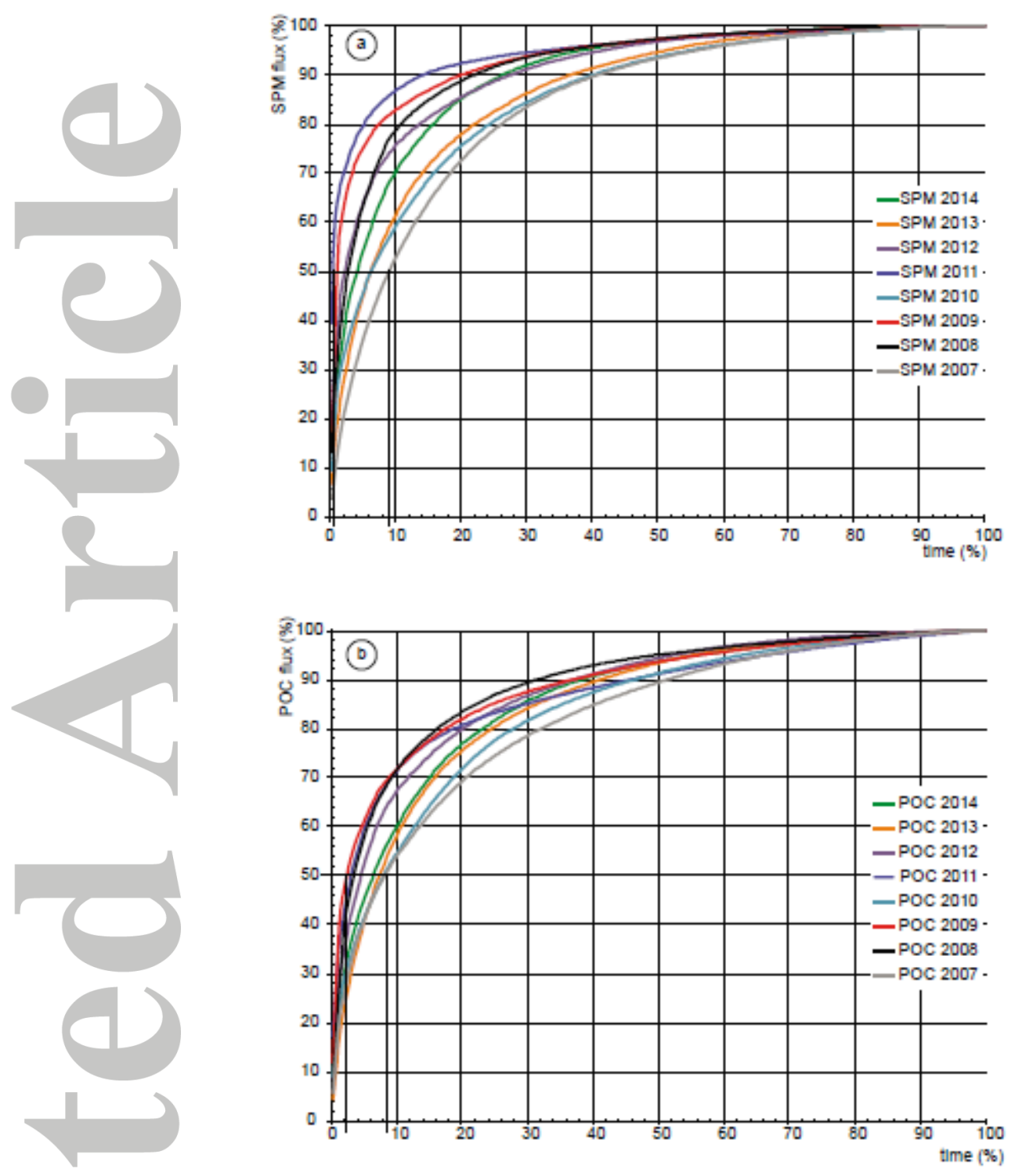

figure 4: SPM and POC fluxes dynamics at the station SORA (years 2007 - 2014),

(a): cumulative percentage of the SPM flux versus cumulative percentage of time, (b): cumulative percentage of the POC flux versus cumulative percentage of time. 


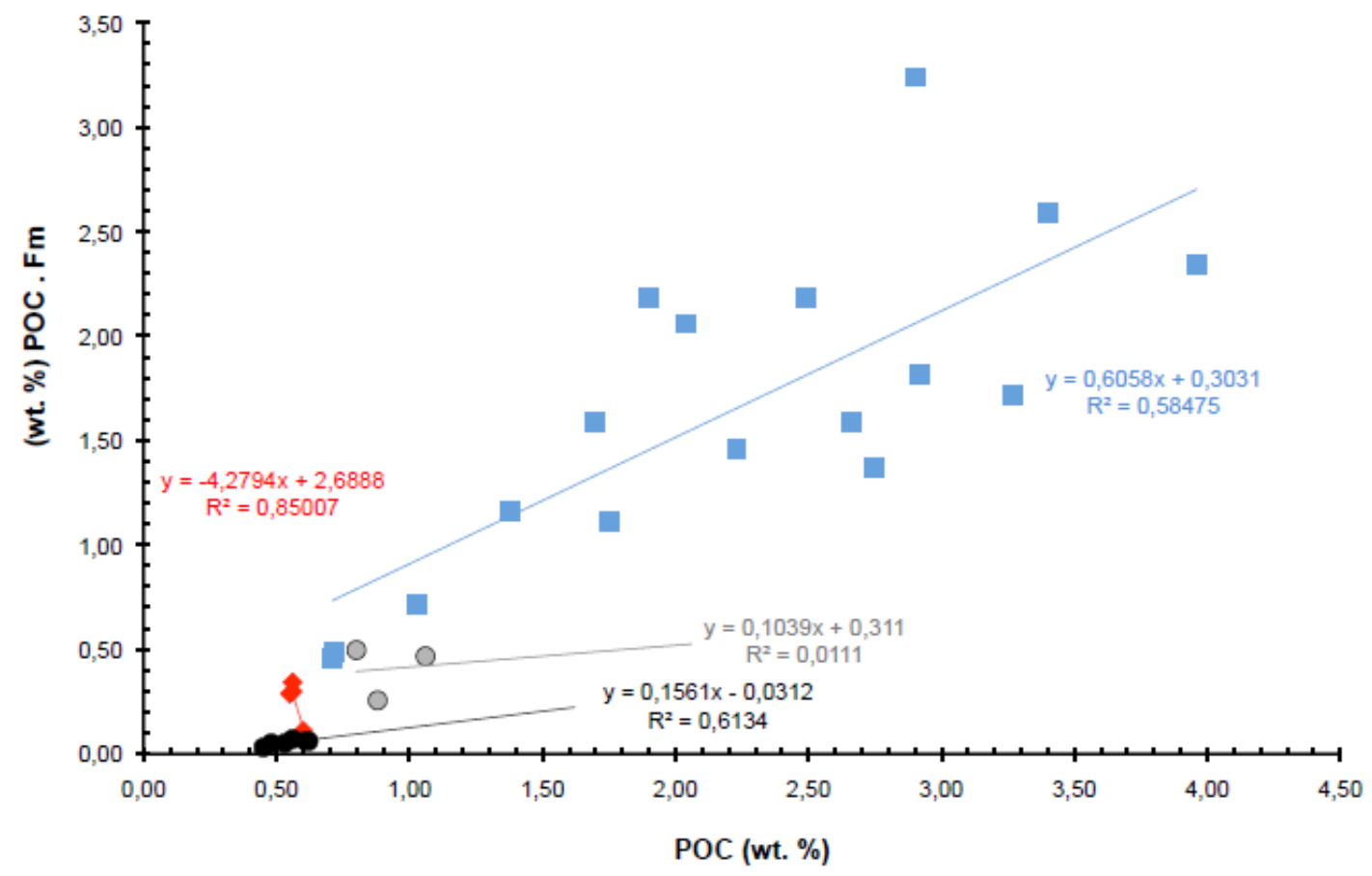

figure 5: Modern rPOC (Fm.POC) content as function of their POC values; SPM with similar PPOC content would be ranged on a linear trend and expressed a binary mixture between $\mathrm{pPOC}$ and $\mathrm{rPOC}$ values. Regarding the equations, intercept with the $x$-axis would give the pPOC content for badlands, Durance and Rhône SPM. Blue squares: Rhône samples, red diamonds: Durance samples, grey circles: Brusquet samples and black circles: Laval samples. Equations and coefficients correlation are given for each samples set. 


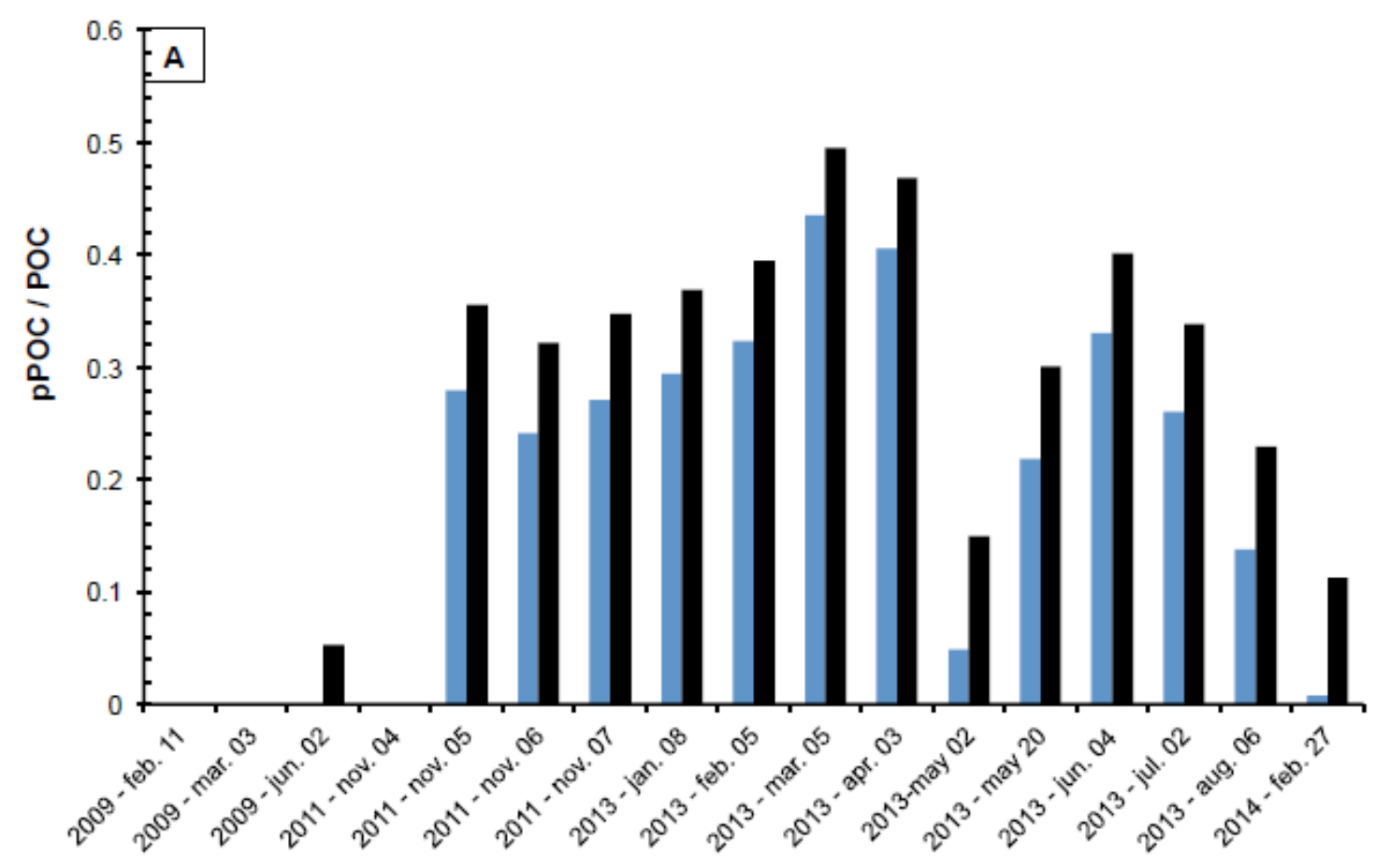

figure 6: $p$ POC / POC ratio after the forward modelling for each studied samples. A: ratio calculated for the samples from the Rhône River and B: ratio calculated for the samples from Durance River and streams draining badlands. For the Rhône and Durance, these ratios are given according to the two rFM values (blue bars: $r F m=$ 0.88 and black bars: $r F m=0.99)$. 

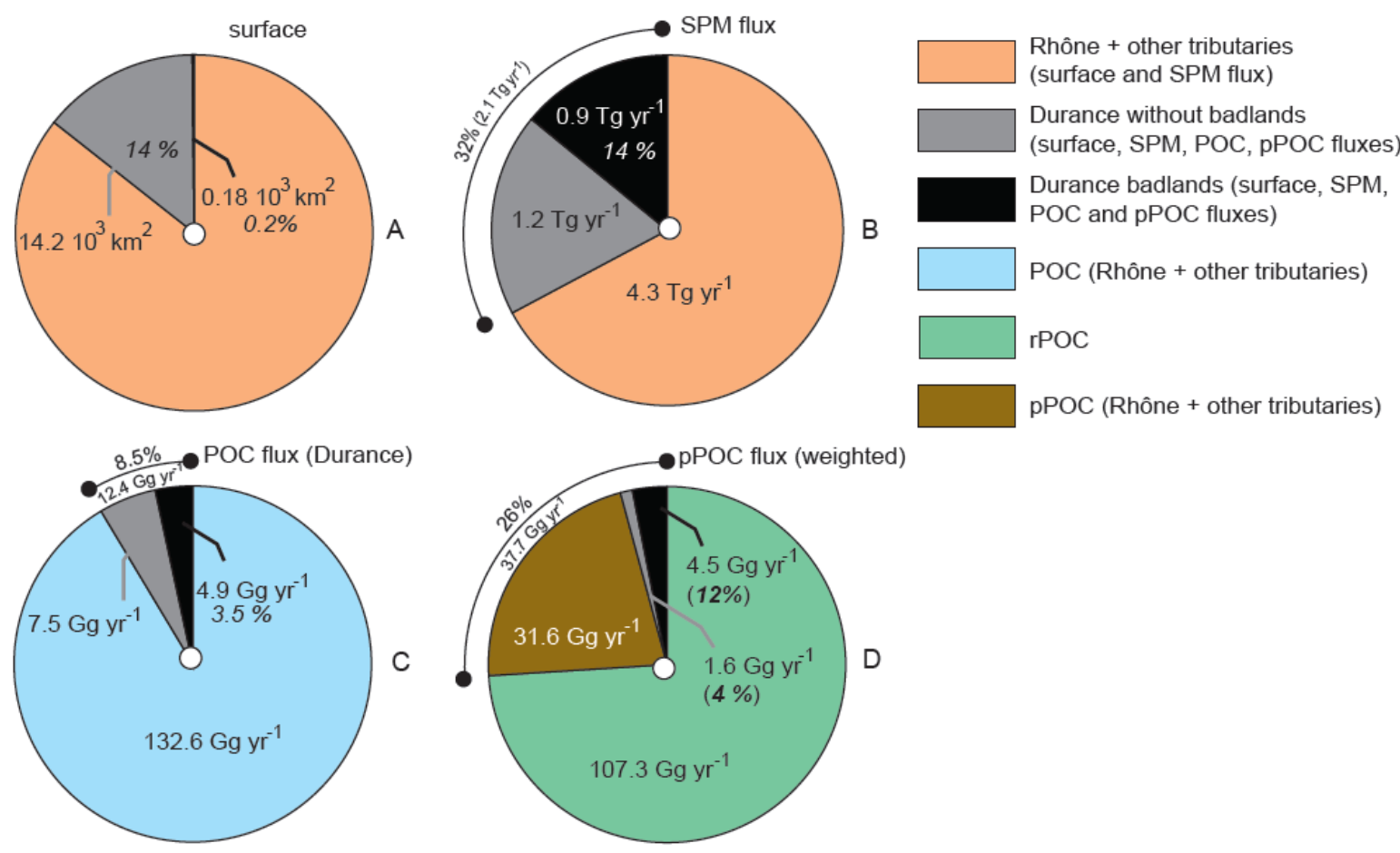

figure 7 : Contribution and values of various parameters and fluxes (surface, SPM and (p)POC) of Durance River and badlands related to those of the Rhône River. A: surface; B: SPM flux; C: POC flux; D: POC flux with the weighted pPOC contribution (26 \%) from 3 sources: Rhône and other tributaries, Durance without badlands and badlands from Durance, percentages given in bold italic correspond to the weighted contribution of the Durance without badlands (4\%) and badlands from Durance $(12 \%)$ to the pPOC flux $\left(37.7 \mathrm{Gg} \mathrm{yr}^{-1}\right)$. 


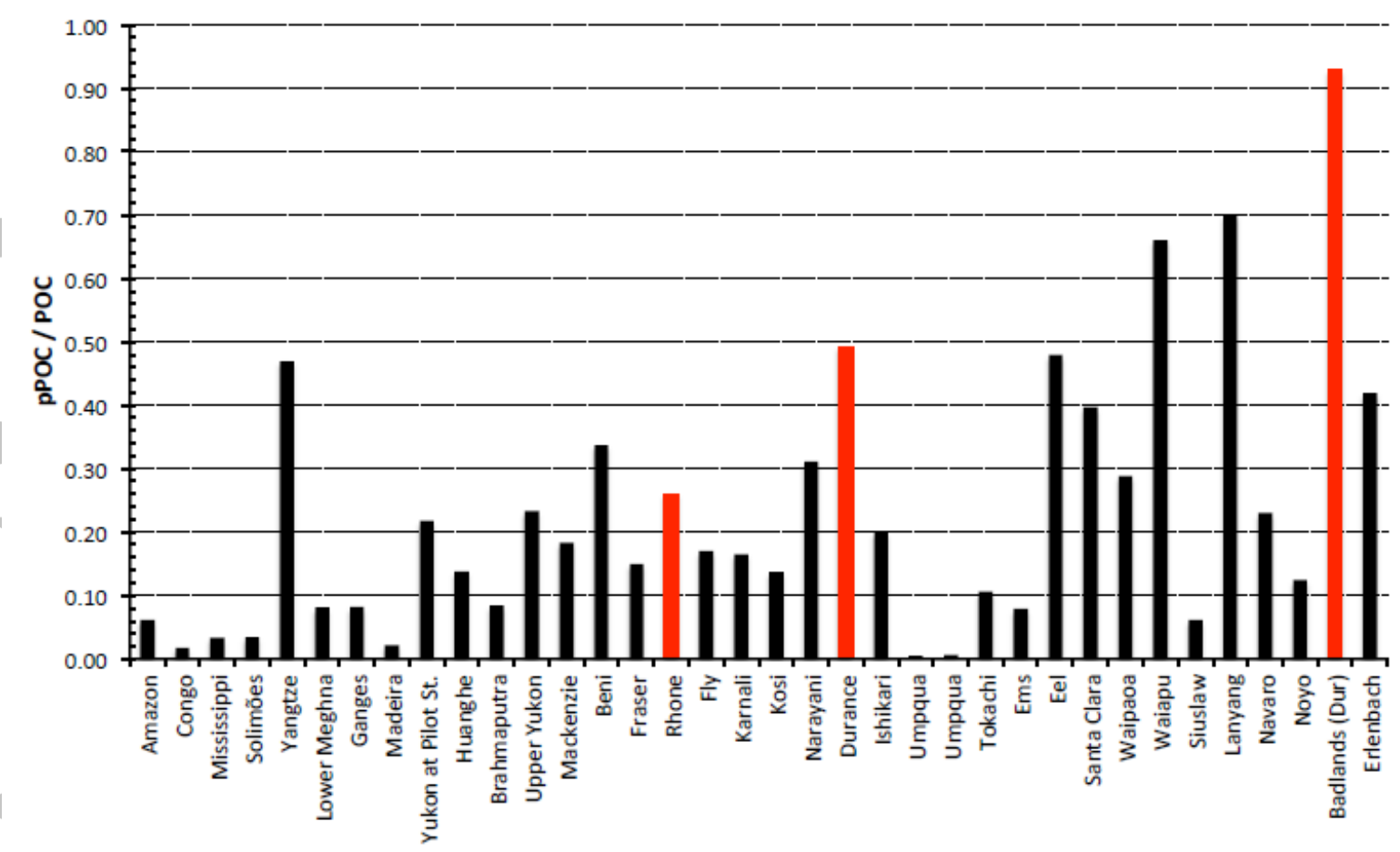

figure 8: compilation of the $\mathrm{PPOC} / \mathrm{POC}$ ratio for the world rivers database (from Galy et al., 2015, supp. Material) ranged following their catchment size, modelled ratio from this study are given in red bars. For the Rhône and badlands from Durance, the ratios are weighted. 
Badlands as a hot spot of petrogenic contribution to riverine particulate Organic Carbon to the Gulf of Lion (NW Mediterranean Sea)

Yoann Copard*, Frédérique Eyrolle, Olivier Radakovitch, Alain Poirel, Patrick Raimbault, Stéphanie Gairoard and Christian Di-Giovanni.

We refine the particulate organic carbon (POC) and sediments flux of the Rhône River. Using ${ }^{14} \mathrm{C}$ data and a forward modelling, a quarter of this $\mathrm{POC}$ has a petrogenic origin. Despite their small surface areas, marly badlands outcropping in the Durance catchment are view as a significant continental source of petrogenic POC and sediments. We suggest that river-dominated ocean margins, as the Rhône River, with badlands in their catchment could export a large amount of pPOC to marine environments.

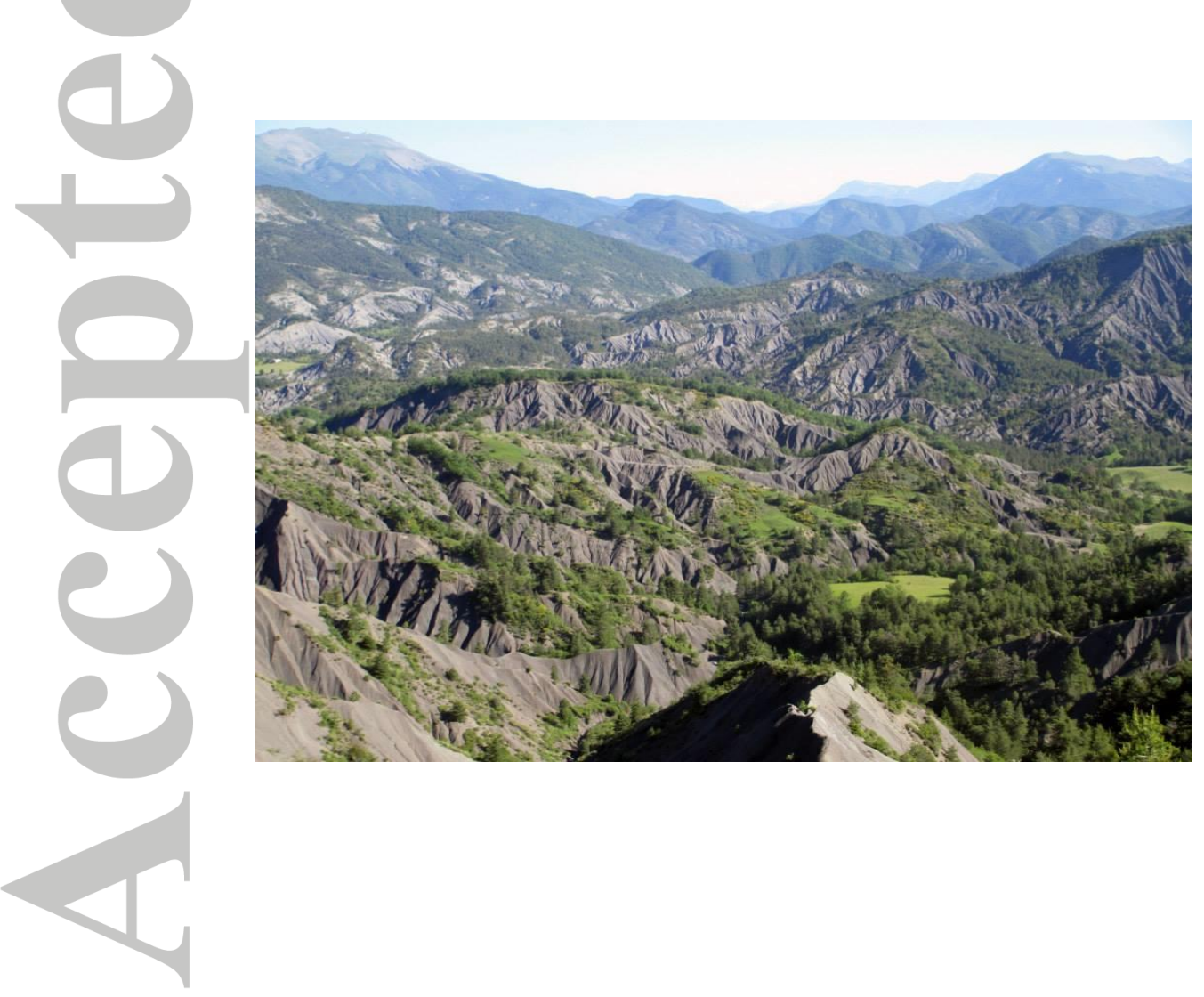

